\title{
Organic Fertilizers Improved Growth and Productivity of Cowpea (Vigna unguiculata (L.) Walp) under Water Stress Condition in El-Arish Region
}

\author{
El-kassas, M. S. ${ }^{1}$; M. A. M. El-hamahmy ${ }^{2 *}$ and A. K. El-Beik ${ }^{3}$ \\ ${ }^{1}$ Soil and water Dep., Fac. of Environ. Agric. Sci., Arish Univ., El-Arish, Egypt. \\ ${ }^{2}$ Agric. Bot. Dep., Fac. of Agric., Suez Canal Univ., Ismailia 41522, Egypt. \\ ${ }^{3}$ Plant production Dep. (vegetables), Fac. of Environ. Agric. Sci., Arish Univ., El-Arish, Egypt.
}

Received: $1 / 1 / 2017$

\begin{abstract}
The effect of three organic fertilizers; viz, chicken manure (ChM, 20 and $40 \mathrm{~m}^{3}$ fed. $\left.^{-1}\right)$, pressed olive cake (POC, 20 and $40 \mathrm{~m}^{3}$ fed. $^{-1}$ ) and cow manure (CwM, 30 and $60 \mathrm{~m}^{3} \mathrm{fed}^{-1}$ ) on growth and productivity of cowpea under water stress condition was investigated. A field experiment was carried out at The Experimental Farm, Fac. Environ. Agric. Sci., Arish Univ., El-Arish, Egypt in summer seasons of 2013 and 2014 in a sandy soil. Irrigation water requirements (IWR) were $50 \%\left(1050 \mathrm{~m}^{3} \mathrm{fed}^{-1}\right)$ and $100 \%\left(2100 \mathrm{~m}^{3} \mathrm{fed}^{-1}\right)$ of the estimated crop evapotranspiration. Results showed that $20 \mathrm{~m}^{3}$ fed. ${ }^{-1}$ of both ChM and POC were more effective for most vegetative growth parameters and yield components in well irrigated-cowpea in both seasons. Water stressed-cowpeas fertilized by $60 \mathrm{~m}^{3} \mathrm{fed}^{-1}$ of CwM showed the lowest reduction in yield (34.07 and 29.86\%) in both seasons, respectively, followed by POC fertilizer at 40 $\mathrm{m}^{3}$ fed. $^{-1}$. Water stressed cowpeas fertilized by $40 \mathrm{~m}^{3}$ fed. ${ }^{-1}$ of POC gave the highest values of water use efficiency $(0.86$ and $0.87 \mathrm{~kg} \mathrm{~m}^{-3}$ ). The lowest total consumed water was recorded with 20 and $40 \mathrm{~m}^{3} \mathrm{fed}^{-1}$ of ChM-fertilized plants under normal and drought conditions. The content of biochemical compounds and macro-elements as well as measurements of some important tissues in leaflet of $3^{\text {rd }}$ leaf related to drought and organic fertilizers were also studied. It was concluded that application of $20 \mathrm{~m}^{3} \mathrm{fed}^{-1}$ of $\mathrm{ChM}$ gave the highest yield in well irrigated-cowpea. Doubled amount of organic fertilizers reduced the deleterious effect of drought especially POC and CwM by saving irrigation water.
\end{abstract}

Keywords: Cowpea, leaflet histology, biochemical, drought, growth, yield.

\section{INTRODUCTION}

Cowpea (Vigna unguiculata (L.) Walp) is an important nutritional legume vegetable, consumed as dry or canned form in Egypt. Seed of cowpea had a 20 $34 \%$ protein, $1.3 \%$ oil, $3.9 \%$ cellulose and $50-67 \%$ carbohydrates (Rochfort and Panozzo, 2007). Cultivated area reached to 4920 fed. in Egypt with a production rate of 7100 ton (FAO-STAT, 2014). Cowpea is widely cultivated in semiarid and tropical regions, but production is limited by the great variation in the amount and distribution of rainfall (Pandey et al., 1984). Although cowpea is relatively drought tolerant legumes but extend of drought period especially at the reproductive stage had a deleterious effect (Ogbonnaya et al., 2003). Estimation of seed yield of cowpea showed that it is drought resistant more than other grain legumes (Pandey et al., 1984). In addition, the effect of drought will be more injurious on plant growth and productivity as in soybean if the irrigated water was saline (Raper and Kramer, 1987).

Drought is a major abiotic stress which negatively affects plant growth, so limiting crop production world-wide (Shangguan et al., 2000). Water stress decreases plant growth by reducing cell division and root enlargement; leads to lowering ion adsorption on the root surface. Also, deficit of water had adversely affect on different physiological process such as photosynthesis, translocation of sugars and phytohormones, ion uptake transport and assimilation, nitrogen fixation, cell turgidity and dark respiration, consequently, yield of different crops was injured. (Fageria et al., 2006). So economic yield of cowpea was reduced by about $35-69 \%$ under drought stress according to timing and length of the drought period (Shouse et al., 1981).

Several physiological mechanisms were done to avoid water stress injury as lowering the transpiration rate by stomatal closure or leaf rolling; osmotic adjustments by accumulation of osmolytes as sugars and proline; reduction and consequently decrease in cellular expansion and alterations of various essential physiological and biochemical processes that can affect growth, yield and quality (Farouk and Amany, 2012).

To overcome the yield reduction of cowpea during water deficit, various tools were used such as selection of new cultivars (Addo-Quaye et al., 2011), agricultural practices as application of organic fertilizers (El-Bassiouny and Shukry, 2001), plant hormones as abscisic acid (Iuchi et al., 2000), had been done. Organic fertilizers were added to improve soil fertility and its physico-chemical properties due to increase soil microbial biomass and activity of soil enzymes (Sun et al., 2003). In addition, organic fertilizers were effective more than chemicals for soil and human health. Moreover, nutrients are less mobile mainly in dry soil because pores are filled with air and pathways for nutrient flux from soil to root surface are less direct. Such conditions in soil limit ion flux to root surface by diffusion and mass flow (Barber, 1995). So, application of organic fertilizers may diminish the deleterious effect of drought on cowpea.

Therefore the present study aimed to investigate the effect of application of recommended (20, 20 and 30 $\left.\mathrm{m}^{3} \mathrm{fed}^{-1}\right)$ and doubled amount $\left(40,40\right.$ and $\left.60 \mathrm{~m}^{3} \mathrm{fed}^{-1}\right)$ of different three organic fertilizers; viz, chicken manure, pressed olive cake and cow manure, respectively on growth and productivity of cowpea under normal and water stress conditions. 


\section{MATERIALS AND METHODS}

\section{Experimental site and conditions}

Two field experiments were carried out during summer seasons of 2013 and 2014 at The Experimental Farm of the Faculty of Environmental Agriculture Sciences, North Sinai, Arish University, Egypt $\left(31^{\circ} 08^{\prime}\right.$ $\mathrm{N}$ latitude, $33^{\circ} 49^{\prime} \mathrm{E}$ longitude and $13 \mathrm{~m}$ above sea level) to study the effect of sources and rates of organic fertilizers as well as water stress on growth and seed yield of cowpea $c v$." Kafr-El Sheikh" grown in sandy soil using drip irrigation system.

Seeds were sown on $20^{\text {th }}$ April in the $1^{\text {st }}$ and $2^{\text {nd }}$ season. Planting was done in rows $15 \mathrm{~cm}$ between hills (two plants hill ${ }^{-1}$ ) on the external sides of double lines, $25 \mathrm{~cm}$ between double lines on the same row and 120 $\mathrm{cm}$ between each two double dripper lines. Experimental unit area was $12 \mathrm{~m}^{2}$ (10 m length and 1.2 $\mathrm{m}$ width). The seeds of cowpea were inoculated with $\mathrm{N}$ fixer (Rhizobium japonica) as recommended using Arabic Gum as an adhesive material. Rhizobia obtained from General Organization for Agriculture Equalization Fund, Ministry of Agriculture and Land Reclamation. The mean monthly climatic data at El-Arish region during the growing seasons of cowpea are presented in Table (1). Some physico-chemical properties of the experimental soil site are shown in Table (2). Soil moisture constants for the experimental soil site were illustrated in Table (3). Chemical analysis of irrigation water is shown in Table (4).

Soil parameters determined before conducting the experiments were particles size distribution (Piper, 1950), total carbonate (Jackson, 1967) and soil $\mathrm{pH}$ value was determined in 1:2.5 soil water suspension. The soil water extract for the 1:5 soil water ratio was chemically analyzed for electrical conductivity (EC) according to Richard (1954) and Jackson (1967).

This experiment included 12 treatments, which were the combinations of two levels of irrigation water requirements (IWR); i.e., $50 \%\left(1050 \mathrm{~m}^{3} \mathrm{fed} .^{-1}\right)$ and $100 \%\left(2100 \mathrm{~m}^{3} \mathrm{fed}^{-1}\right)$ of IWR of the estimated crop evapotranspiration (ETc) and three types of organic fertilizer (chicken manure $(\mathrm{ChM})$ at a rate of 20 and 40 $\mathrm{m}^{3}$ fed. $^{-1}$; pressed olive cake (POC) at a rate of 20 and $40 \mathrm{~m}^{3}$ fed. $^{-1}$ and cow manure $(\mathrm{CwM})$ at a rate of 30 and $60 \mathrm{~m}^{3}$ fed. $^{-1}$. The chemical analysis of each organic fertilizer is illustrated in Table (5).

Irrigation treatments were applied at the second true leaf stage. In the two growing seasons, the amount of water needed for each irrigation was calculated according to the crop coefficient $(\mathrm{Kc})$ and the daily reference potential evapotranspiration (ETo).Treatments were randomly arranged in a spilt-split plot system in a complete randomized block design with three replicates. Organic fertilizers were allowed randomly to main plots, rates of organic fertilizers were assigned randomly in sub plots, while irrigation levels were distributed randomly in sub-sub plots. The normal agricultural practices were done as needed and similar to those used in commercial cowpea production in ElArish region.

\section{Data recorded}

\section{Water relationships}

1. Consumptive use of water (CU): It was calculated using the equation given by Israelson and Hansen (1962) as follows:

\section{Where:}

$$
\mathrm{CU}=\mathrm{D} \times \mathrm{AD} \times[(\mathrm{ez}-\mathrm{ei}) \times 100]
$$

$\mathrm{CU}=$ Consumptive use of water in $\mathrm{cm}$,

$\mathrm{D}=$ Irrigated soil depth in $\mathrm{cm}$,

$\mathrm{AD}=$ Bulk density, $\mathrm{gm} \mathrm{cm}^{-3}$, of the chosen irrigated soil depth,

$\mathrm{ez}=$ Soil moisture percent after irrigation, and

$\mathrm{ei}=$ Soil moisture percent before the next irrigation.

2. Water use efficiency (WUE): The consumed water by cowpea plant was calculated according to Yaron et al. (1973) as follows:

$$
\mathrm{WUE}=\mathrm{Y} / \mathrm{ETa}
$$

Where:

$\mathrm{Y}=$ Crop yield $\left(\mathrm{kg}_{\mathrm{fed}} \mathrm{f}^{-1}\right)$, and

$\mathrm{ETa}=$ Evapotranspiration $\left(\mathrm{m}^{3} \cdot \mathrm{fed}^{-1}\right.$.)

The actual evapotranspiration, ETa, is assumed to be synonymous to the calculated consumptive use of water (C.U). Consequently, daily and monthly consumptive use of water was calculated for specified soil depths for all treatments.

3. The yield reduction and water saving were calculated from the following equations according to Ismail, 2010.

Reduction in yield $=100-[$ (Yield of $75 \%$ of WR or $50 \%$ of WR/ Yield of $100 \%$ of WR) x 100]

Water saving $=100-[$ (Water consumption of $75 \%$ of WR or $50 \%$ of WR/ Water consumption of $100 \%$ of WR) $\times 100]$

Where:

$\mathrm{WR}=$ Water requirements

Table (1): The mean monthly climatic data at El-Arish Governorate during the growing periods of cowpea in 2013 and

\begin{tabular}{|c|c|c|c|c|c|c|c|c|c|c|c|c|c|c|c|c|}
\hline \multirow{3}{*}{ Months } & \multicolumn{6}{|c|}{ Temperature ${ }^{0} \mathrm{C}$} & \multicolumn{6}{|c|}{ RH (\%) } & \multicolumn{4}{|c|}{ Wind speed $\left(\mathrm{Kmh}^{-1}\right)$} \\
\hline & \multicolumn{2}{|c|}{ Max. } & \multicolumn{2}{|c|}{ Min. } & \multicolumn{2}{|c|}{ Avg. } & \multicolumn{2}{|c|}{ Max. } & \multicolumn{2}{|c|}{ Min. } & \multicolumn{2}{|c|}{ Avg. } & \multicolumn{2}{|c|}{ Max. } & \multicolumn{2}{|c|}{ Avg. } \\
\hline & 13 & 14 & 13 & 14 & 13 & 14 & 13 & 14 & & 14 & & 14 & & & & 14 \\
\hline April & 25.1 & 25.9 & 12.0 & 12.7 & 18.7 & 19.3 & 93.2 & 98.0 & 27.0 & 36.9 & 62.5 & 75.2 & 20.7 & 16.8 & 8.2 & 5.2 \\
\hline May & 29.2 & 28.6 & 15.8 & 16.7 & 22.5 & 22.5 & 96.2 & 91.1 & 30.9 & 34.9 & 67.6 & 68.4 & 18.0 & 16.7 & 6.8 & 5.2 \\
\hline June & 30.8 & 30.9 & 18.9 & 18.9 & 24.9 & 24.9 & 95.5 & 92.8 & 33.9 & 33.4 & 66.9 & 69.1 & 21.9 & 16.9 & 6.7 & 5.1 \\
\hline July & 30.7 & 31.8 & 21.4 & 21.3 & 26.1 & 26.5 & 93.7 & 94.8 & 41.6 & 43.4 & 70.3 & 73.6 & 18.8 & 15.0 & 7.1 & 5.1 \\
\hline August & 32.3 & 32.5 & 21.3 & 22.3 & 26.9 & 27.6 & 96.1 & 94.6 & 41.7 & 43.9 & 72.7 & 73.3 & 16.2 & 15.8 & 5.9 & 5.0 \\
\hline
\end{tabular}
2014 seasons 
Table (2): Initial soil physical and chemical analysis

\begin{tabular}{|c|c|c|c|c|c|c|c|}
\hline \multirow{4}{*}{\multicolumn{2}{|c|}{ Soil properties }} & \multicolumn{6}{|c|}{ Seasons } \\
\hline & & \multicolumn{3}{|c|}{2013} & \multicolumn{3}{|c|}{2014} \\
\hline & & \multicolumn{6}{|c|}{ Depth (cm.) } \\
\hline & & $0-15$ & $15-30$ & $30-45$ & $0-15$ & $15-30$ & $30-45$ \\
\hline \multicolumn{8}{|c|}{ Mechanical analysis } \\
\hline \multicolumn{2}{|c|}{ Coarse sand \% } & 68.00 & 69.22 & 62.70 & 68.56 & 69.92 & 65.41 \\
\hline \multicolumn{2}{|c|}{ Fine sand \% } & 22.60 & 21.41 & 28.90 & 22.98 & 20.02 & 24.12 \\
\hline \multicolumn{2}{|l|}{ Silt \% } & 3.50 & 3.12 & 2.95 & 3.21 & 3.52 & 4.60 \\
\hline \multicolumn{2}{|c|}{ Clay $\%$} & 5.90 & 6.25 & 5.45 & 5.25 & 6.54 & 5.87 \\
\hline \multicolumn{2}{|c|}{ Soil texture } & Sandy & Sandy & Sandy & Sandy & Sandy & Sandy \\
\hline \multicolumn{2}{|c|}{ Bulk density $\left({\left.\mathrm{g} . \mathrm{cm}^{-3}\right)}^{-3}\right.$} & 1.62 & 1.63 & 1.67 & 1.65 & 1.63 & 1.67 \\
\hline \multicolumn{8}{|c|}{ Chemical analysis (soluble ions in (1:5) extract) } \\
\hline $\mathrm{Ca}^{++}$ & $\left(\right.$meq..$\left.^{-1}\right)$ & 2.48 & 3.12 & 2.08 & 3.06 & 3.61 & 2.66 \\
\hline $\mathbf{M g}^{++}$ & $\left(\mathbf{m e q} \cdot \mathbf{l}^{-1}\right)$ & 2.11 & 2.31 & 2.22 & 2.37 & 2.13 & 2.60 \\
\hline $\mathrm{Na}^{+}$ & $\left(\right.$meq..$\left.^{-1}\right)$ & 1.21 & 1.46 & 1.89 & 2.97 & 2.44 & 2.49 \\
\hline $\mathbf{K}^{+}$ & $\left(\operatorname{meq} . \mathrm{I}^{-1}\right)$ & 0.30 & 0.31 & 0.21 & 0.40 & 0.22 & 0.35 \\
\hline $\mathrm{HCO}_{3}^{-}$ & $\left(\right.$meq..$\left.^{-1}\right)$ & 2.16 & 2.71 & 2.41 & 2.60 & 2.40 & 2.90 \\
\hline $\mathrm{Cl}^{-}$ & $\left(\mathbf{m e q} \cdot \mathrm{l}^{-1}\right)$ & 1.25 & 1.80 & 1.36 & 1.88 & 2.61 & 2.64 \\
\hline $\mathrm{SO}_{4}^{--}$ & $\left(\right.$meq..$\left.^{-1}\right)$ & 2.69 & 2.69 & 2.63 & 4.32 & 3.39 & 2.56 \\
\hline \multicolumn{2}{|c|}{ Available N (ppm) } & 18.50 & 16.98 & 16.54 & 18.24 & 16.42 & 15.40 \\
\hline \multicolumn{2}{|c|}{ Available P (ppm) } & 45.55 & 46.22 & 44.52 & 46.21 & 44.01 & 41.61 \\
\hline \multicolumn{2}{|c|}{ Available K (ppm) } & 90.56 & 91.60 & 90.51 & 98.20 & 96.30 & 93.06 \\
\hline \multicolumn{2}{|c|}{$E C\left(d S m^{-1}\right)$ in $(1: 5)$ extract $)$} & 0.61 & 0.72 & 0.64 & 0.88 & 0.84 & 0.81 \\
\hline \multicolumn{2}{|c|}{ pH in $(1: 2.5)$ extract $)$} & 8.23 & 8.21 & 8.20 & 8.02 & 8.04 & 8.10 \\
\hline \multicolumn{2}{|c|}{$\mathrm{CaCO}_{3} \%$} & 5.95 & 7.67 & 6.15 & 5.95 & 7.65 & 6.16 \\
\hline
\end{tabular}

Table (3): Soil moisture constants for the experimental soil site

\begin{tabular}{|c|c|c|c|c|c|c|c|c|}
\hline \multirow[b]{2}{*}{$\begin{array}{l}\text { Depth } \\
\text { (cm.) }\end{array}$} & \multicolumn{2}{|c|}{ Saturation percentage } & \multicolumn{2}{|c|}{ Field capacity } & \multicolumn{2}{|c|}{ Wilting point } & \multicolumn{2}{|c|}{ Available water } \\
\hline & $\begin{array}{l}g . g^{-1} \\
(\%)\end{array}$ & $\begin{array}{l}\text { Soil moisture } \\
(\mathbf{m m} / \mathbf{1 5 c m})\end{array}$ & $\begin{array}{l}\text { g. } g^{-1} \\
(\%)\end{array}$ & $\begin{array}{c}\text { Soil moisture } \\
(\mathbf{m m} / \mathbf{1 5} \mathrm{cm})\end{array}$ & $\begin{array}{l}\text { g. } g^{-1} \\
(\%)\end{array}$ & $\begin{array}{c}\text { Soil } \\
\text { moisture } \\
(\mathbf{m m} / \mathbf{1 5 c m})\end{array}$ & $\begin{array}{l}\text { g.g } g^{-1} \\
(\%)\end{array}$ & $\begin{array}{c}\text { Soil moisture } \\
(\mathbf{m m} / \mathbf{1 5 c m})\end{array}$ \\
\hline $0-15$ & 28.92 & 66.37 & 7.50 & 17.21 & 3.21 & 7.37 & 4.29 & 9.85 \\
\hline $15-30$ & 28.29 & 64.50 & 7.71 & 17.58 & 3.13 & 7.14 & 4.58 & 10.44 \\
\hline $30-45$ & 30.04 & 70.29 & 7.32 & 17.13 & 3.14 & 7.35 & 4.18 & 9.78 \\
\hline
\end{tabular}

Table (4): Chemical analysis of irrigation water

\begin{tabular}{|c|c|c|c|c|c|c|c|c|c|}
\hline \multirow{3}{*}{$\mathbf{p H}$} & \multicolumn{3}{|c|}{$E C$} & \multicolumn{4}{|c|}{ Soluble ions $\left(\right.$ meq. $\left.^{-1}\right)$} & & \\
\hline & \multirow{2}{*}{$\mathrm{dSm}^{-1}$} & \multirow{2}{*}{ ppm } & \multicolumn{4}{|c|}{ Cations } & \multicolumn{3}{|c|}{ Anions } \\
\hline & & & $\mathrm{Ca}^{++}$ & $\mathrm{Mg}^{++}$ & $\mathrm{Na}^{+}$ & $\mathbf{K}^{+}$ & $\mathrm{Cl}^{-}$ & $\mathrm{HCO}_{3}^{-}$ & $\mathrm{SO}_{4}^{--}$ \\
\hline \multicolumn{10}{|c|}{ First season } \\
\hline 7.04 & 6.41 & 4102.4 & 20.13 & 24.21 & 19.31 & 0.21 & 46.62 & 7.01 & 10.23 \\
\hline \multicolumn{10}{|c|}{ Second season } \\
\hline 7.23 & 6.29 & 4025.6 & 19.86 & 24.01 & 18.81 & 0.23 & 44.51 & 8.21 & 10.19 \\
\hline
\end{tabular}


Table (5): Chemical analysis of organic fertilizers under study

\begin{tabular}{ccccc}
\hline \multirow{2}{*}{$\begin{array}{c}\text { Organic fertilizer } \\
\text { contents }\end{array}$} & \multicolumn{5}{c}{ Organic fertilizer } \\
\cline { 2 - 5 } & Cow manure & Chicken manure & Pressed Olive Cake \\
\hline Total N\% & 2.7 & 3.2 & 2.3 \\
Total P\% & 0.4 & 0.2 & 0.3 \\
Total K\% & 2.1 & & 2.0 & 2.1 \\
\hline & & Second season & & 2.4 \\
\hline Total N\% & 2.8 & 3.3 & 0.4 \\
Total P\% & 0.3 & 0.3 & 1.9 \\
\hline
\end{tabular}

\section{Growth and yield parameters}

At 70 days after sowing (at $50 \%$ of flowering) all vegetative and physiological parameters were estimated. Stem length $(\mathrm{cm})$, number of both branches and leaves plant $^{-1}$ were recorded. Fresh and dry weight plant ${ }^{-1}(\mathrm{~g})$ was determined after drying at $70^{\circ} \mathrm{C}$ up to constant weight. Plant water content (\%) was calculated as follow: (Fresh weight - dry weight) $/($ fresh weight) $\times$ 100. Leaf blade area $\left(\mathrm{cm}^{2}\right)$ was determined by scanning the terminal leaflet of $3^{\text {rd }}$ leaf with a leaf area meter (AM 300). At harvest (after 120 days of sowing), seed yield $\left(\mathrm{kg} \mathrm{fed}^{-1}\right), 100$ seed weight $(\mathrm{g})$, pod length $(\mathrm{cm})$ and number of seedspod ${ }^{-1}$ were determined. Net yield $(\%)$ was estimated as seed yield / pods yield.

\section{Chemical constituents}

\section{Chlorophyll assay}

According to Arnon (1949), $0.5 \mathrm{~g}$ of the terminal leaflets of $3^{\text {rd }}$ leaf was ground with $10 \mathrm{ml}$ acetone $85 \%$ and filtered. Optical density was measured at 440.5, 644 and $662 \mathrm{~nm}$ using a Beckman DK-2 Spectrophotometer (T80, UV/VIS spectrometer, PG instrument Ltd, USA) to determine the concentration of chlorophyll $\mathrm{a}, \mathrm{b}$ and carotenoids as mg $100 \mathrm{~g}^{-1} \mathrm{FW}$, respectively.

\section{Reducing sugars, free phenolics and amino acids}

Ethanol extract $(96 \%$ EOH) of the terminal leaflets of $3^{\text {rd }}$ leaf was prepared according to AbdelRahman et al. (1975). Reducing sugars were determined spectrophotometricaly at $540 \mathrm{~nm}$ according to Moore (1974). Free phenolics were determined spectrophotometricaly at $650 \mathrm{~nm}$ according to William et al. (1965). Free amino acids were estimated spectrophotometricaly at $570 \mathrm{~nm}$ using the method of Rosen (1957). Free proline was assayed in fresh flag leaf according to Bates et al. (1973), L-proline was used as a standard.

\section{Soluble Protein}

Soluble protein content (mg $\mathrm{g}^{-1}$ FW) was determined using bovine serum albumin (BSA) as a standard, according to the method of Bradford (1976), using $1 \mathrm{ml}$ Bradford solution and $100 \mu \mathrm{l}$ leaf extract.

\section{Nitrogen, phosphorus, sodium and potassium leaves content}

Random sample of the terminal leaflets of $3^{\text {rd }}$ leaf from each experimental unit was dried at $70 \mathrm{C}$ until the constant weight. Then $0.5 \mathrm{~g}$ of powdered material was digested using a mixture of sulfuric acid $\left(\mathrm{H}_{2} \mathrm{SO}_{4}\right)$ and hydrogen peroxide $\left(\mathrm{H}_{2} \mathrm{O}_{2}\right)$ and then brought to a final volume of $50 \mathrm{~mL}$ with distilled water. The content of $\mathrm{N}$, $\mathrm{P}, \mathrm{Na}$ and $\mathrm{K}$ was determined by flame photometer model III (Carl Zeiss Jena, Germany) according to Brown and Lilleland (1946).

\section{Histological investigations}

Terminal leaflets of $3^{\text {rd }}$ leaf specimens from second season plants were fixed in F.A.A., dehydrated in ethyl alcohol series, embedded in Paraffin wax, sectioned to thickness of $15 \mu \mathrm{m}$, double stained with Safranin and Light green, cleared in Xylene and mounted in Canada balsam according to Willey (1971). All measurements were calculated by eyepiece micrometer.

\section{Statistical analysis}

All statistical analyses were performed with SPSS version 13.0 (SPSS Inc., Chicago, IL, USA). Data at each time point were analyzed by one-way ANOVA, and mean separations were performed by L.S.D test. Differences at $\mathrm{P}<0.05$ were considered significant.

\section{RESULTS}

\section{Effect of organic fertilizers}

Growth parameters

Application of $20 \mathrm{~m}^{3} \mathrm{fed}^{-1}$ of $\mathrm{ChM}$ was more effective on stem length and leaf area of terminal leaflet of $3^{\text {rd }}$ leaf in normal irrigated-cowpea plants than other fertilizers as shown in Table (6). Application of $20 \mathrm{~m}^{3}$ fed. $^{-1}$ of POC was valuable for enhancing number of branches and leaves plant ${ }^{-1}, \mathrm{FW}, \mathrm{DW}$ and percent of water content than ChM and CwM in well irrigatedcowpeas. In most cases, the higher dosages of all organic fertilizers enhanced the most investigated growth parameters in well watered-plants. The maximum significant values of stem length and number of branches plant ${ }^{-1}$ was recorded with $40 \mathrm{~m}^{3}$ fed. $^{-1}$ of POC-fertilized plants cultivated under normal irrigated conditions. Plants fertilized with $60 \mathrm{~m}^{3} \mathrm{fed}^{-1}$ of ChM gave the highest values of FW and DW plant ${ }^{-1}$. Reduction of irrigated water negatively affected the most investigated growth parameters and the lowest values of reduction were observed in ChM-fertilized plants. The higher amount of all three examined organic fertilizers overcome the reduction of most growth 
Table (6): Effect of organic fertilizers on growth parameters of cowpea cv. 'Kafr-Elsheikh' cultivated under different water regimes in 2013 and 2014 seasons

\begin{tabular}{|c|c|c|c|c|c|c|c|c|c|c|c|c|c|c|c|c|}
\hline \multicolumn{2}{|c|}{ Organic Fertilizers } & \multirow{2}{*}{ IWR } & \multicolumn{2}{|c|}{ Stem length (cm) } & \multicolumn{2}{|c|}{$\begin{array}{l}\text { N. of branches } \\
\text { plant }^{-1}\end{array}$} & \multicolumn{2}{|c|}{ N. of leaves plant ${ }^{-1}$} & \multicolumn{2}{|c|}{ FW plant ${ }^{-1}(g)$} & \multicolumn{2}{|c|}{ DW plant $^{-1}(g)$} & \multicolumn{2}{|c|}{$\begin{array}{c}\text { Water content } \\
(\%)\end{array}$} & \multicolumn{2}{|c|}{$\begin{array}{c}\text { Leaflet area of } 3^{\text {rd }} \\
\text { leaf }\left(\mathrm{cm}^{2}\right)\end{array}$} \\
\hline Source & $\begin{array}{c}\text { Rates } \\
\left(\mathbf{m}^{-3} \text { fed }^{-1}\right)\end{array}$ & & 2013 & 2014 & 2013 & 2014 & 2013 & 2014 & 2013 & 2014 & 2013 & 2014 & 2013 & $\begin{array}{c}201 \\
4\end{array}$ & 2013 & 2014 \\
\hline \multirow{4}{*}{ ChM } & & $\mathrm{W}_{1}$ & $46.0 \mathrm{a}$ & $44.0 \mathrm{abc}$ & $2.0 \mathrm{~b}$ & $2.0 \mathrm{~b}$ & $11.0 \mathrm{c}$ & $10.0 \mathrm{c}$ & $97.5 \mathrm{abc}$ & $91.7 \mathrm{abc}$ & $26.7 \mathrm{bc}$ & $26.0 \mathrm{bcd}$ & $73.2 \mathrm{ab}$ & 71.9 & $63.4 \mathrm{a}$ & $57.0 \mathrm{a}$ \\
\hline & & W 0.5 & $32.3 \mathrm{bc}$ & $29.7 \mathrm{~cd}$ & $4.7 \mathrm{ab}$ & $3.7 \mathrm{ab}$ & $14.3 \mathrm{bc}$ & $13.3 \mathrm{bc}$ & $74.9 \mathrm{bc}$ & $68.7 \mathrm{c}$ & $25.5 \mathrm{bc}$ & $23.0 \mathrm{bcd}$ & $64.9 \mathrm{ab}$ & 65.6 & $43.4 \mathrm{ab}$ & $38.7 \mathrm{ab}$ \\
\hline & & $\mathrm{W}_{1}$ & $48.0 \mathrm{ab}$ & $47.7 \mathrm{ab}$ & $4.7 \mathrm{ab}$ & $4.0 \mathrm{ab}$ & $23.7 \mathrm{~b}$ & $22.0 \mathrm{~b}$ & $165.6 \mathrm{a}$ & $154.0 \mathrm{a}$ & $43.0 \mathrm{a}$ & $39.3 \mathrm{a}$ & $69.2 \mathrm{ab}$ & 69.3 & $47.9 \mathrm{a}$ & $41.0 \mathrm{ab}$ \\
\hline & & W 0.5 & $44.0 \mathrm{ab}$ & $42.7 \mathrm{abc}$ & $3.3 \mathrm{ab}$ & $2.7 \mathrm{~b}$ & $14.7 \mathrm{bc}$ & $13.3 \mathrm{bc}$ & $80.6 \mathrm{bc}$ & $73.3 \mathrm{bc}$ & $29.5 \mathrm{bc}$ & $25.3 \mathrm{bcd}$ & $62.7 \mathrm{ab}$ & 65.0 & $45.1 \mathrm{ab}$ & $42.3 \mathrm{ab}$ \\
\hline \multirow{4}{*}{ POC } & & $\mathrm{W}_{1}$ & $22.3 \mathrm{c}$ & $23.7 \mathrm{~d}$ & $4.0 \mathrm{ab}$ & $3.0 \mathrm{ab}$ & $39.3 \mathrm{a}$ & $38.3 \mathrm{a}$ & $154.9 \mathrm{ab}$ & $146.7 \mathrm{ab}$ & $36.7 \mathrm{abc}$ & $33.0 \mathrm{abcd}$ & $75.4 \mathrm{a}$ & 76.0 & $26.1 \mathrm{~b}$ & $24.0 \mathrm{~b}$ \\
\hline & & W 0.5 & $47.3 \mathrm{ab}$ & $44.3 \mathrm{abc}$ & $3.3 \mathrm{ab}$ & $3.0 \mathrm{ab}$ & $11.0 \mathrm{c}$ & $10.7 \mathrm{c}$ & $64.1 \mathrm{c}$ & $60.0 \mathrm{c}$ & $24.5 \mathrm{c}$ & $22.3 \mathrm{~cd}$ & $61.6 \mathrm{ab}$ & 62.7 & $46.3 \mathrm{ab}$ & $43.0 \mathrm{ab}$ \\
\hline & & $\mathrm{W}_{1}$ & $59.7 \mathrm{a}$ & $53.0 \mathrm{a}$ & $6.0 \mathrm{a}$ & $5.3 \mathrm{a}$ & $17.3 \mathrm{bc}$ & $16.7 \mathrm{bc}$ & $129.8 \mathrm{abc}$ & $123.0 \mathrm{abc}$ & $38.7 \mathrm{ab}$ & $35.7 \mathrm{abc}$ & $66.2 \mathrm{ab}$ & 64.9 & $43.3 \mathrm{ab}$ & $39.7 \mathrm{ab}$ \\
\hline & & W 0.5 & $43.0 \mathrm{ab}$ & $41.3 \mathrm{abc}$ & $3.7 \mathrm{ab}$ & $2.7 \mathrm{~b}$ & $11.7 \mathrm{bc}$ & $11.7 \mathrm{c}$ & $69.3 \mathrm{c}$ & $68.7 \mathrm{c}$ & $27.5 \mathrm{bc}$ & $22.7 \mathrm{bcd}$ & $59.6 \mathrm{~b}$ & 65.7 & $46.9 \mathrm{ab}$ & $40.3 \mathrm{ab}$ \\
\hline \multirow{4}{*}{ CwM } & & $\mathrm{W}_{1}$ & $37.3 \mathrm{bc}$ & $34.0 \mathrm{bcd}$ & $1.7 \mathrm{~b}$ & $1.7 \mathrm{~b}$ & $15.3 \mathrm{bc}$ & $13.7 \mathrm{bc}$ & $107.1 \mathrm{abc}$ & $97.7 \mathrm{abc}$ & $30.0 \mathrm{abc}$ & $26.0 \mathrm{bcd}$ & $70.3 \mathrm{ab}$ & 72.9 & $56.8 \mathrm{a}$ & $53.0 \mathrm{a}$ \\
\hline & & W 0.5 & $34.0 \mathrm{bc}$ & $33.0 \mathrm{bcd}$ & $3.3 \mathrm{ab}$ & $2.7 \mathrm{~b}$ & $12.7 \mathrm{bc}$ & $11.0 \mathrm{c}$ & $67.9 \mathrm{c}$ & $63.3 \mathrm{c}$ & $23.3 \mathrm{c}$ & $21.3 \mathrm{~d}$ & $64.2 \mathrm{ab}$ & 65.1 & $47.8 \mathrm{a}$ & $43.7 \mathrm{ab}$ \\
\hline & & $\mathrm{W}_{1}$ & $42.0 \mathrm{ab}$ & $39.7 \mathrm{abc}$ & $3.0 \mathrm{ab}$ & $2.7 \mathrm{~b}$ & $18.3 \mathrm{bc}$ & $19.3 \mathrm{bc}$ & $148.1 \mathrm{abc}$ & $136.7 \mathrm{abc}$ & $36.9 \mathrm{abc}$ & $36.0 \mathrm{ab}$ & $74.4 \mathrm{a}$ & 73.9 & $50.6 \mathrm{a}$ & $47.7 \mathrm{a}$ \\
\hline & & W 0.5 & $37.3 \mathrm{bc}$ & $35.7 \mathrm{bcd}$ & $2.7 \mathrm{~b}$ & $2.7 \mathrm{~b}$ & $12.0 \mathrm{bc}$ & $10.7 \mathrm{c}$ & $79.1 \mathrm{bc}$ & $79.7 \mathrm{abc}$ & $26.4 \mathrm{bc}$ & $24.0 \mathrm{bcd}$ & $65.6 \mathrm{ab}$ & 69.4 & $54.4 \mathrm{a}$ & $47.0 \mathrm{a}$ \\
\hline \multicolumn{2}{|c|}{ LSD at $5 \%$} & & 16.7 & 13.9 & 2.65 & 2.32 & 10.78 & 8.74 & 72.68 & 67.6 & 12.1 & 11.6 & 12.35 & $\begin{array}{c}14.6 \\
\text { ns }\end{array}$ & 18.8 & 17.7 \\
\hline
\end{tabular}

Mean values followed by the same letter in each bar show non-significantly different at the $\mathrm{P}<0.05$ probability level

IWR: Irrigation water requirements W0: Well watered (2100 m-3 fad.)W 0.5: Water stressed (1050 m-3 fad.) ChM: Chicken manure POC: Pressed Olive Cake CwM: Cow manure 
parameters of water stressed-plants, especially in ChM fertilized-ones. In this respect, the higher amount of ChM compensates the reduction of stem length by 36.2 and $43.7 \%$ in both seasons compared to water stress cowpeas. FW and leaf area were enhanced by 16.5 and $25.9 \%, 13.8$ and $7.5 \%$ in CwM-fertilized plants in the first and second seasons, respectively. DW enhanced by $15.6 \%$ in the first season in ChM-fertilized plants and by $12.6 \%$ in CwM-fertilized ones in the second season.

\section{Yield components}

In general, low amount of both $\mathrm{ChM}$ and POC fertilizers was more effective on most investigated yield parameters in well watered plants than that of $\mathrm{CwM}$ as shown in Table (7). Higher amount of all three organic fertilizers enhanced the most yield parameters in nonstressed water plants. The maximum value of seed yield (kg fed. ${ }^{-1}$ ) was recorded with $\mathrm{ChM}$ and POC-fertilized plants under normal irrigated conditions. The most yield parameters were differed according to cultivated season. Decreasing amount of irrigation water reduced the most investigated yield parameters in all three different fertilized cowpeas. The lowest reduction in yield was recorded in POC-fertilized plants. Higher amount of $\mathrm{ChM}$ and $\mathrm{CwM}$ improved the yield of cowpeas under water stress. However, ChM-fertilized plants showed about 9.4 and $10.3 \%$; 4.9 and $12.2 \%$ increment of both net weight and weight of 100 seed compared to water stressed ones in the first and second seasons, respectively.

\section{Plant water-relations}

\section{Water consumptive use (CU)}

Values of water consumptive use (CU) were more influenced by irrigation water levels than by the sources and rates of organic fertilizer (Table 8). Generally, sufficient irrigation water increased CU under any source and rate of organic fertilizers. The highest value of CU (1812.12 and $\left.1842.31 \mathrm{~m}^{3} \mathrm{fed}^{-1}\right)$ was recorded with application of $60 \mathrm{~m}^{3} \mathrm{fed}^{-1}$ of $\mathrm{CwM}$ under normal irrigation conditions in the first and second season, respectively. The lowest CU value (616.51 and $621.54 \mathrm{~m}^{3} \mathrm{fed}^{-1}$ ) was recorded with application of 20 $\mathrm{m}^{3} \mathrm{fed}^{-1}$ of ChM under $50 \%$ of IWR in both seasons. Doubled amount of all three organic fertilizers under study soil conditions increased the CU with 100 and $50 \%$ of IWR.

\section{Yield reduction and water saving}

Increasing all investigated organic fertilizers rates with lowering the irrigation water amount led to water saving more than $60 \%$ and lowering the reduction of seed yield (Table 8). Although, seed yield of cowpea decreased by more than half under $50 \%$ of IWR with ChM or POC fertilizers, but CwM-fertilized plants lost only 36.13 and $33.59 \%$ of seed yield in first and second season, respectively. Doubled fertilized-cowpea with CwM had only 34.07 and $29.86 \%$ of yield reduction under $50 \%$ of IWR compared to 59.32 and $58.20 ; 43.69$ and $42.42 \%$ under $\mathrm{ChM}$ and POC in first and second season, respectively.

\section{Water Use Efficiency (WUE)}

In all cases, doubled amount of all organic fertilizers increased the WUE of both well and stressed water plants (Table 8). The highest value of WUE $(0.87$ and $0.86 \mathrm{~kg} \mathrm{~m}^{-3}$ ) was obtained with application of doubled amount POC under $50 \%$ of IWR treatment than ChM and CwM.

\section{Photosynthetic pigments}

Under normal irrigated conditions CwMfertilized plants had high amount of Ch.a, b and carotenoids than POC and ChM fertilizers (Table 9). Well-watered plants fertilized with high amount of POC had the highest content of Ch.a, $b$ and $a+b$. The maximum significant value of carotenoids was observed in non-water stressed plants fertilized with low amount of CwM. Lowering water irrigated amount reduced the content of Ch.b and carotenoids of POC and CwMfertilized plants. Higher dose of organic fertilizers lowered the reduction of pigments as a result of water stress, especially CwM. CwM-fertilized plants which were lowered by about $65.2 \%$ for Chl. b and $34.2 \%$ for Chl. a+b. ChM enhanced the amount of Chl.a by $20.2 \%$ compared to water stressed plants.

\section{Organic and non-organic chemical compounds}

Recommend amount of POC under normal irrigation conditions resulted in plants with high content of reducing sugars, free phenolics, soluble protein and potassium than other organic fertilizers (Table 10). Addition of low amount of CwM resulted in high value of proline and $\mathrm{P}$. ChM in low amount resulted in the high amount of nitrogen and $\mathrm{Na}$. Under high amount of $\mathrm{ChM}$, plants had the highest content of reducing sugars, free phenols, soluble protein and phosphorus under normal water conditions. Proline content was higher in plants fertilized with high amount of $\mathrm{CwM}$ than other fertilizers under non-water stress. Most of estimated chemical compounds were decreased with reduction of water irrigation in low POC-fertilized plants, but addition of ChM and CwM increased the amount of reducing sugars, free phenolics, soluble protein, proline and $\mathrm{Na}$ content. Higher amount of POC and CwM improved the content of reducing sugars, free phenolics and $\mathrm{K}$ under water stress conditions. POC increased the content of reducing sugars by $14.5 \%$ and $\mathrm{P}$ by $53.7 \%$. $\mathrm{CwM}$ increased the content of phenolics by $13.9 \%$ and $\mathrm{K}$ by 61.6 . ChM increased the protein content by $25.9 \%$ compared to water stressed plants.

\section{Anatomical characters of terminal leaflet of $3^{\text {rd }}$ leaf}

Under normal irrigation conditions, plants fertilized with low amount of ChM gave higher values of thickness of spongy tissue, intercellular space, number of xylem arms bundles ${ }^{-1}$, number of vessels bundles $^{-1}$, Phloem in the main vascular bundle, xylem thickness, number of vessels bundles ${ }^{-1}$ in the second vascular bundle than other fertilizers (Table 11 and Fig. 1). Plants fertilized with low amount of POC had the higher values of thickness of mesophyll and epidermis, palisade tissue, number of arms bundles ${ }^{-1}$ and phloem in the secondary vascular bundle. Higher amount of the three different organic fertilizers increased the number of arms bundle ${ }^{-1}$, number of vessels bundle ${ }^{-1}$ in main vascular bundle and number of arms bundle ${ }^{-1}$ in the secondary vascular bundle. With reducing irrigated water, the most histological characters of leaf were decreased under ChM and POC fertilization, but these characters were increased in CwM-fertilized plants. 
Leaflets of ChM-fertilized plants showed increment by $29 \%$ for the thickness of palisade tissue, $47.6 \%$ for xylem thickness, $28.9 \%$ for number of arms bundles ${ }^{-1}$, $66.6 \%$ for number of vessels bundles ${ }^{-1}$ and $22.8 \%$ for phloem thickness in the main vascular bundle and $6.2 \%$ for phloem thickness in the secondary vascular bundle. POC-fertilized plants showed increment of the intercellular spaces by $105.9 \%$, xylem thickness by $26.6 \%$ and number of arms bundle ${ }^{-1}$ by $30.3 \%$ in the secondary vascular bundle.

Table (7): Effect of organic fertilizers on yield parameters of cowpea cv. 'Kafr-Elsheikh' cultivated under different water regimes in 2013 and 2014 seasons

\begin{tabular}{|c|c|c|c|c|c|c|c|c|c|c|c|c|}
\hline \multicolumn{2}{|c|}{$\begin{array}{c}\text { Organic } \\
\text { Fertilizers }\end{array}$} & \multirow[b]{2}{*}{ IWR } & \multicolumn{2}{|c|}{$\begin{array}{c}\text { Net weight } \\
(\%)\end{array}$} & \multicolumn{2}{|c|}{$\begin{array}{l}\text { Seed yield } \\
\left(\mathrm{kg} \mathrm{fed}^{-1}\right)\end{array}$} & \multicolumn{2}{|c|}{$\begin{array}{l}\text { Weight of } 100 \\
\text { seed (g) }\end{array}$} & \multicolumn{2}{|c|}{$\begin{array}{l}\text { Pod length } \\
\text { (cm) }\end{array}$} & \multicolumn{2}{|c|}{$\begin{array}{l}\text { Number of } \\
\text { seeds pod }^{-1}\end{array}$} \\
\hline Source & $\begin{array}{c}\text { Rates } \\
\left(\mathrm{m}^{-3}\right. \\
\left.\text { fed. }^{-1}\right)\end{array}$ & & 2013 & 2014 & 2013 & 2014 & 2013 & 2014 & 2013 & 2014 & 2013 & 2014 \\
\hline \multirow{3}{*}{ ChM } & \multirow{2}{*}{20} & $\mathbf{W}_{1}$ & $80.7 \mathrm{c}$ & 73.6ab & $1100 \mathrm{~b}$ & $1120 \mathrm{~b}$ & $15.2 \mathrm{a}$ & $19.8 \mathrm{bcd}$ & $20.3 a$ & $18.8 \mathrm{ab}$ & $13.4 \mathrm{a}$ & $11.9 \mathrm{abc}$ \\
\hline & & W 0.5 & $80.2 \mathrm{c}$ & $65.2 \mathrm{c}$ & $420 \mathrm{~g}$ & $460 \mathrm{i}$ & $14.2 \mathrm{bc}$ & $18.8 \mathrm{def}$ & $19.6 \mathrm{bc}$ & $16.4 \mathrm{~d}$ & $12.7 b$ & $9.8 \mathrm{~d}$ \\
\hline & 40 & $\mathbf{W}_{1}$ & $80.1 \mathrm{c}$ & $69.5 \mathrm{bc}$ & $1180 \mathrm{a}$ & $1220 \mathrm{a}$ & $14.7 \mathrm{ab}$ & $20.4 \mathrm{ab}$ & $18.7 \mathrm{de}$ & $18.9 \mathrm{a}$ & $11.8 \mathrm{c}$ & $12.1 \mathrm{abc}$ \\
\hline \multirow{4}{*}{ POC } & \multirow{2}{*}{20} & $\mathbf{W}_{1}$ & $78.7 \mathrm{c}$ & $72.6 \mathrm{ab}$ & $1000 d$ & $990 d$ & $15.2 \mathrm{a}$ & $19.8 b c$ & 19.7abc & $18.8 \mathrm{a}$ & $13.7 \mathrm{a}$ & $12.4 \mathrm{ab}$ \\
\hline & & W 0.5 & $80.9 \mathrm{c}$ & 71.6ab & $420 \mathrm{~h}$ & $430 \mathrm{i}$ & $13.5 \mathrm{c}$ & $18.9 \mathrm{cde}$ & $19.2 \mathrm{~cd}$ & $17.5 \mathrm{c}$ & $13.5 \mathrm{a}$ & $11.7 \mathrm{abc}$ \\
\hline & \multirow{2}{*}{40} & $\mathrm{~W}_{1}$ & $80.3 \mathrm{c}$ & $76.5 \mathrm{a}$ & $1030 \mathrm{c}$ & $1040 \mathrm{c}$ & $13.3 \mathrm{c}$ & $19.5 \mathrm{bcd}$ & $19.8 \mathrm{abc}$ & $17.7 \mathrm{bc}$ & $13.9 \mathrm{a}$ & $11.8 \mathrm{abc}$ \\
\hline & & W 0.5 & $89.2 \mathrm{a}$ & $75.0 \mathrm{ab}$ & $580 \mathrm{e}$ & $600 \mathrm{e}$ & $14.7 \mathrm{ab}$ & $19.8 \mathrm{bcd}$ & $18.2 \mathrm{ef}$ & $17.4 \mathrm{~cd}$ & $13.5 \mathrm{a}$ & $11.7 \mathrm{abc}$ \\
\hline \multirow{4}{*}{ CwM } & \multirow{2}{*}{30} & $\mathbf{W}_{1}$ & $83.0 \mathrm{bc}$ & $70.4 b c$ & $500 \mathrm{f}$ & $510 \mathrm{~g}$ & $15.3 \mathrm{a}$ & $17.9 \mathrm{fg}$ & $18.2 \mathrm{ef}$ & $17.4 \mathrm{~cd}$ & $11.5 \mathrm{c}$ & $11.5 \mathrm{bc}$ \\
\hline & & W 0.5 & $90.1 \mathrm{a}$ & $57.9 \mathrm{~d}$ & $320 \mathrm{j}$ & $340 \mathrm{k}$ & $14.0 \mathrm{bc}$ & $18.5 \mathrm{efg}$ & $18.5 \mathrm{e}$ & $18.7 \mathrm{ab}$ & $12.4 \mathrm{~b}$ & $12.9 \mathrm{a}$ \\
\hline & \multirow{2}{*}{60} & $\mathbf{W}_{1}$ & $78.5 \mathrm{c}$ & $75.3 \mathrm{ab}$ & $550 \mathrm{~g}$ & $460 \mathrm{f}$ & $14.5 \mathrm{ab}$ & $17.8 \mathrm{~g}$ & $18.9 \mathrm{de}$ & $17.8 \mathrm{abc}$ & $12.5 \mathrm{~b}$ & $11.8 \mathrm{abc}$ \\
\hline & & W 0.5 & $83.7 \mathrm{bc}$ & $71.5 \mathrm{ab}$ & $360 \mathrm{i}$ & $390 \mathrm{j}$ & $14.7 \mathrm{ab}$ & $20.2 \mathrm{ab}$ & $17.7 \mathrm{f}$ & $17.0 \mathrm{~cd}$ & $11.6 \mathrm{c}$ & $11.3 \mathrm{bc}$ \\
\hline \multicolumn{2}{|c|}{ LSD at $5 \%$} & & 5.39 & 5.8 & 7.04 & 2.11 & 0.918 & 0.976 & 0.604 & 1.00 & 0.528 & 1.087 \\
\hline
\end{tabular}

Mean values followed by the same letter in each bar show non-significantly different at the $\mathrm{P}<0.05$ probability level

IWR: Irrigation water requirements W0: Well watered (2100 m-3 fad.) W 0.5: Water stressed (1050 m-3 fad.) ChM: Chicken manure POC: Pressed Olive Cake CwM: Cow manure

Table (8): Effect of organic fertilizers and irrigation water levels on total consumed water, reduction of yield, water saving and water use efficiency of cowpea during 2013 and 2014 seasons

\begin{tabular}{|c|c|c|c|c|c|c|c|c|c|c|}
\hline \multicolumn{2}{|c|}{$\begin{array}{c}\text { Organic } \\
\text { Fertilizers }\end{array}$} & \multirow{2}{*}{ IWR } & \multirow[t]{2}{*}{$\begin{array}{c}\text { Total } \\
\text { consumed } \\
\text { water } \\
\left(\mathbf{m}^{3} \mathbf{f e d}^{-1}\right) \\
\end{array}$} & \multirow[t]{2}{*}{$\begin{array}{l}\text { Reduction } \\
\text { in yield \% }\end{array}$} & \multirow[t]{2}{*}{$\begin{array}{c}\text { Water } \\
\text { saving \% }\end{array}$} & \multirow[t]{2}{*}{$\begin{array}{c}\text { Water } \\
\text { use } \\
\text { efficiency } \\
\left(\mathrm{kgm}^{-3}\right) \\
\end{array}$} & \multirow[t]{2}{*}{$\begin{array}{c}\text { Total } \\
\text { consumed } \\
\text { water } \\
\left(\mathbf{m}^{3} \mathbf{f e d}^{-1}\right) \\
\end{array}$} & \multirow[t]{2}{*}{$\begin{array}{l}\text { Reduction } \\
\text { in yield \% }\end{array}$} & \multirow[t]{2}{*}{$\begin{array}{c}\text { Water } \\
\text { saving \% }\end{array}$} & \multirow[t]{2}{*}{$\begin{array}{c}\text { Water } \\
\text { use } \\
\text { efficiency } \\
\left(\mathrm{kgm}^{-3}\right) \\
\end{array}$} \\
\hline Source & $\begin{array}{c}\text { Rates } \\
\left(\mathbf{m}^{-3}\right. \\
\left.\text { fed. }^{-1}\right)\end{array}$ & & & & & & & & & \\
\hline \multirow{4}{*}{ ChM } & \multirow{2}{*}{20} & $\mathbf{W}_{1}$ & 1689.32 & - & - & 0.65 & 1719.02 & - & - & 0.65 \\
\hline & & W 0.5 & 616.51 & 61.82 & 63.51 & 0.68 & 621.54 & 58.93 & 63.84 & 0.74 \\
\hline & \multirow{2}{*}{40} & $\mathbf{W}_{1}$ & 1732.03 & - & - & 0.68 & 1743.20 & - & - & 0.70 \\
\hline & & W 0.5 & 634.12 & 59.32 & 63.39 & 0.76 & 685.21 & 58.20 & 60.69 & 0.74 \\
\hline \multirow{4}{*}{ POC } & \multirow{2}{*}{20} & $\mathbf{W}_{1}$ & 1745.56 & - & - & 0.57 & 1764.48 & - & - & 0.56 \\
\hline & & W 0.5 & 663.63 & 57.82 & 61.98 & 0.63 & 671.88 & 56.42 & 61.91 & 0.64 \\
\hline & \multirow{2}{*}{40} & $\mathbf{W}_{1}$ & 1772.64 & - & - & 0.58 & 1792.31 & - & - & 0.58 \\
\hline & & W 0.5 & 664.56 & 43.69 & 62.50 & 0.87 & 700.66 & 42.42 & 60.92 & 0.86 \\
\hline \multirow{4}{*}{ CwM } & \multirow{2}{*}{30} & $\mathbf{W}_{1}$ & 1801.52 & - & - & 0.28 & 1809.22 & - & - & 0.28 \\
\hline & & W 0.5 & 693.14 & 36.13 & 61.52 & 0.46 & 716.11 & 33.59 & 60.42 & 0.47 \\
\hline & \multirow{2}{*}{60} & $\mathbf{W}_{1}$ & 1812.15 & - & - & 0.30 & 1842.31 & - & - & 0.30 \\
\hline & & W 0.5 & 712.61 & 34.07 & 60.68 & 0.51 & 722.21 & 29.86 & 60.80 & 0.54 \\
\hline
\end{tabular}


Table (9): Effect of organic fertilizers on photosynthetic pigments contained of the terminal leaflet of $3^{\text {rd }}$ leaf of cowpea cv. 'Kafr-Elsheikh' cultivated under different water regimes

\begin{tabular}{|c|c|c|c|c|c|c|c|}
\hline \multicolumn{2}{|c|}{ Organic Fertilizers } & \multirow{3}{*}{ IWR } & \multirow{2}{*}{ Ch.a } & \multirow{2}{*}{ Ch.b } & \multirow{2}{*}{ Carotenoids } & \multirow{2}{*}{ Ch.a +b } & \multirow{2}{*}{ Ch.a/b } \\
\hline \multirow{2}{*}{ Source } & \multirow{2}{*}{$\begin{array}{c}\text { Rates } \\
\left(\mathrm{m}^{-3} \text { fed. }^{-1}\right)\end{array}$} & & & & & & \\
\hline & & & \multicolumn{4}{|c|}{$\mathrm{mg} / 100 \mathrm{~g} \mathrm{FW}$} & \\
\hline \multirow{4}{*}{ ChM } & \multirow{2}{*}{20} & $\mathbf{W}_{1}$ & $42.1 \mathrm{~h}$ & $26.2 \mathrm{~h}$ & $27.0 \mathrm{~g}$ & $68.3 \mathrm{f}$ & $1.6 \mathrm{a}$ \\
\hline & & W 0.5 & $19.3 \mathrm{j}$ & $34.0 \mathrm{e}$ & $34.2 \mathrm{c}$ & $53.3 \mathrm{~g}$ & $0.57 \mathrm{f}$ \\
\hline & \multirow{2}{*}{40} & $\mathbf{W}_{1}$ & $65.3 \mathrm{~b}$ & $42.2 \mathrm{~d}$ & $34.1 \mathrm{c}$ & $107.4 \mathrm{~b}$ & $1.5 \mathrm{~b}$ \\
\hline & & W 0.5 & $23.2 \mathrm{i}$ & $42.2 \mathrm{~d}$ & 31.2 ef & $65.5 \mathrm{f}$ & $0.57 \mathrm{f}$ \\
\hline \multirow{4}{*}{ POC } & \multirow{2}{*}{20} & $\mathbf{W}_{1}$ & $51.3 \mathrm{f}$ & $30.1 \mathrm{f}$ & $32.1 \mathrm{de}$ & $81.4 \mathrm{~d}$ & $1.7 \mathrm{a}$ \\
\hline & & W 0.5 & $55.0 \mathrm{e}$ & $47.2 \mathrm{c}$ & $30.1 \mathrm{f}$ & $102.3 \mathrm{c}$ & $1.2 \mathrm{~d}$ \\
\hline & \multirow{2}{*}{40} & $\mathbf{W}_{1}$ & $73.1 \mathrm{a}$ & $62.0 \mathrm{a}$ & $37.3 \mathrm{~b}$ & $135.0 \mathrm{a}$ & $1.2 \mathrm{~d}$ \\
\hline & & W 0.5 & $55.2 \mathrm{e}$ & $49.1 \mathrm{~b}$ & $33.2 \mathrm{~cd}$ & $104.3 \mathrm{bc}$ & $1.1 \mathrm{e}$ \\
\hline \multirow{4}{*}{ CwM } & \multirow{2}{*}{30} & $\mathbf{W}_{1}$ & $58.5 \mathrm{~cd}$ & $47.0 \mathrm{c}$ & $40.3 \mathrm{a}$ & $105.5 \mathrm{bc}$ & $1.3 \mathrm{~d}$ \\
\hline & & W 0.5 & $48.1 \mathrm{~g}$ & $28.2 \mathrm{~g}$ & $30.2 \mathrm{f}$ & $76.4 \mathrm{e}$ & $1.7 \mathrm{a}$ \\
\hline & \multirow{2}{*}{60} & $\mathbf{W}_{1}$ & $59.2 \mathrm{c}$ & $43.0 \mathrm{~d}$ & $34.1 \mathrm{c}$ & $102.2 \mathrm{c}$ & $1.4 \mathrm{c}$ \\
\hline & & W 0.5 & $56.0 \mathrm{de}$ & $46.6 \mathrm{c}$ & $30.1 \mathrm{f}$ & $102.6 \mathrm{c}$ & $1.2 \mathrm{~d}$ \\
\hline \multicolumn{2}{|c|}{ LSD at $5 \%$} & & 2.8 & 1.68 & 1.75 & 3.54 & 0.079 \\
\hline
\end{tabular}

Mean values followed by the same letter in each bar show non-significantly different at the $\mathrm{P}<0.05$ probability level

IWR: Irrigation water requirements W0: Well watered (2100 m-3 fad.) W 0.5: Water stressed (1050 m-3 fad.) ChM: Chicken manure

POC: Pressed Olive Cake CwM: Cow manure

Table (10): Effect of organic fertilizers on content of organic and non-organic substances in leaflet of $3^{\text {rd }}$ leaf of cowpea cv. 'Kafr-Elsheikh' cultivated under different water regimes

\begin{tabular}{|c|c|c|c|c|c|c|c|c|c|c|}
\hline \multicolumn{2}{|c|}{ Organic Fertilizers } & \multirow{3}{*}{ IWR } & \multicolumn{4}{|c|}{ Biomolecules } & \multicolumn{4}{|c|}{ Elements } \\
\hline \multirow{2}{*}{ Source } & \multirow{2}{*}{$\begin{array}{c}\text { Rates } \\
\left(\mathrm{m}^{-3} \text { fed. }^{-1}\right)\end{array}$} & & \multirow{2}{*}{$\begin{array}{c}\begin{array}{l}\text { Reducin } \\
\text { g sugars }\end{array} \\
{ }_{1}^{\mathrm{mg} \mathrm{10g}} \mathbf{F W}\end{array}$} & $\begin{array}{c}\text { Free } \\
\text { phenolics }\end{array}$ & Proline & protein & $\mathbf{N}$ & $\mathbf{P}$ & $\mathbf{N a}$ & $\mathbf{K}$ \\
\hline & & & & mg 100 & FW & $\begin{array}{c}\mathrm{mg} \mathrm{g}^{-1} \\
\text { FW }\end{array}$ & & & & \\
\hline \multirow{4}{*}{ ChM } & \multirow{2}{*}{20} & $\mathbf{W}_{1}$ & $85.1 \mathrm{e}$ & $71.3 \mathrm{e}$ & $24.2 \mathrm{e}$ & $15.3 \mathrm{f}$ & $1.20 \mathrm{a}$ & $.085 \mathrm{de}$ & $8.5 b$ & $0.717 \mathrm{abc}$ \\
\hline & & W 0.5 & $115.2 b$ & $74.2 \mathrm{~d}$ & $32.9 b$ & $15.8 \mathrm{f}$ & $1.00 \mathrm{bc}$ & $.087 \mathrm{~cd}$ & $8.7 \mathrm{a}$ & $0.467 \mathrm{e}$ \\
\hline & \multirow{2}{*}{40} & $\mathbf{W}_{1}$ & $119.2 \mathrm{a}$ & $115.2 \mathrm{a}$ & $30.3 \mathrm{~cd}$ & $31.1 \mathrm{a}$ & $0.917 \mathrm{bcd}$ & $0.121 \mathrm{a}$ & $6.1 \mathrm{f}$ & $0.81 \mathrm{ab}$ \\
\hline & & W 0.5 & $109.1 \mathrm{c}$ & $72.3 \mathrm{e}$ & $22.0 \mathrm{f}$ & $19.9 \mathrm{de}$ & $0.84 \mathrm{~d}$ & $0.088 \mathrm{~cd}$ & $8.5 b$ & $0.677 b c$ \\
\hline \multirow{4}{*}{ POC } & \multirow{2}{*}{20} & $\mathbf{W}_{1}$ & $110.3 \mathrm{c}$ & $91.1 \mathrm{~b}$ & $24.2 \mathrm{e}$ & $22.1 \mathrm{c}$ & $1.03 \mathrm{~b}$ & $0.105 b$ & $6.4 \mathrm{~cd}$ & $0.85 \mathrm{a}$ \\
\hline & & W 0.5 & $84.1 \mathrm{e}$ & $59.1 \mathrm{~g}$ & $31.1 \mathrm{c}$ & $19.3 \mathrm{de}$ & $0.90 \mathrm{~cd}$ & $0.082 \mathrm{de}$ & $6.37 \mathrm{cde}$ & $0.367 \mathrm{e}$ \\
\hline & \multirow{2}{*}{40} & $\mathbf{W}_{1}$ & $97.1 \mathrm{~d}$ & $91.8 \mathrm{~b}$ & $29.3 d$ & $29.7 b$ & $0.89 \mathrm{~cd}$ & $0.101 b c$ & $6.2 \mathrm{ef}$ & $0.627 \mathrm{~cd}$ \\
\hline & & W 0.5 & $96.3 \mathrm{~d}$ & $66.2 \mathrm{f}$ & $19.7 \mathrm{~g}$ & $20.5 d$ & $0.70 \mathrm{e}$ & $0.126 \mathrm{a}$ & $6.27 \mathrm{def}$ & $0.373 \mathrm{e}$ \\
\hline \multirow{4}{*}{ CwM } & \multirow{2}{*}{30} & $\mathbf{W}_{1}$ & $70.0 \mathrm{~h}$ & $53.2 \mathrm{~h}$ & $31.0 \mathrm{c}$ & $18.7 \mathrm{e}$ & $0.92 \mathrm{bcd}$ & $0.119 \mathrm{a}$ & $6.4 \mathrm{~cd}$ & $0.71 \mathrm{abc}$ \\
\hline & & W 0.5 & $80.0 \mathrm{~g}$ & $71.2 \mathrm{e}$ & $31.0 \mathrm{c}$ & $20.5 \mathrm{~d}$ & $0.80 \mathrm{de}$ & $0.071 \mathrm{ef}$ & $6.50 \mathrm{c}$ & $0.497 \mathrm{de}$ \\
\hline & \multirow{2}{*}{60} & $\mathbf{W}_{1}$ & $66.1 \mathrm{i}$ & $51.0 \mathrm{i}$ & $39.1 \mathrm{a}$ & $19.9 \mathrm{de}$ & $0.89 \mathrm{~cd}$ & $0.089 \mathrm{~cd}$ & $4.33 \mathrm{~g}$ & $0.633 \mathrm{~cd}$ \\
\hline & & W 0.5 & $82.1 \mathrm{f}$ & $81.1 \mathrm{c}$ & $31.1 \mathrm{c}$ & $15.2 \mathrm{f}$ & $0.81 \mathrm{de}$ & $0.062 f$ & $6.20 \mathrm{ef}$ & $0.803 \mathrm{ab}$ \\
\hline \multicolumn{2}{|c|}{ LSD at $5 \%$} & & 1.74 & 1.86 & 1.54 & 1.32 & 0.113 & 0.014 & 0.161 & 0.149 \\
\hline
\end{tabular}

Mean values followed by the same letter in each bar show non-significantly different at the $\mathrm{P}<0.05$ probability level

IWR: Irrigation water requirements W0: Well watered (2100 m-3 fad.) W 0.5: Water stressed (1050 m-3 fad.) ChM: Chicken manure POC: Pressed Olive Cake CwM: Cow manure 
Table (11): Effect of organic fertilizers on anatomical parameters of $3^{\text {rd }}$ leaf of cowpea cv. 'Kafr-Elsheikh' cultivated under different water regimes

\begin{tabular}{|c|c|c|c|c|c|c|c|c|c|c|c|c|c|c|}
\hline \multirow{2}{*}{\multicolumn{2}{|c|}{ Organic Fertilizers }} & \multirow{4}{*}{ IWR } & \multicolumn{4}{|c|}{ Blade } & \multicolumn{8}{|c|}{ Midrib } \\
\hline & & & \multirow[b]{3}{*}{$\begin{array}{c}\text { Mesophyll } \\
\text { and epidermis }\end{array}$} & \multicolumn{3}{|c|}{ Thickness $(\mu \mathrm{m})$ of } & \multicolumn{4}{|c|}{ Main vascular bundle } & \multicolumn{4}{|c|}{ Second vascular bundle } \\
\hline \multirow[b]{2}{*}{ Source } & \multirow[b]{2}{*}{$\begin{array}{c}\text { Rates } \\
\left(\mathrm{m}^{3} \text { fed. }^{-1}\right)\end{array}$} & & & & & & & xylem & & Phloem & & xylem & & Phloem \\
\hline & & & & $\begin{array}{l}\text { Palisade } \\
\text { tissue }\end{array}$ & $\begin{array}{l}\text { Spongy } \\
\text { tissue }\end{array}$ & $\begin{array}{l}\text { intercellular } \\
\text { space }\end{array}$ & $\begin{array}{l}\text { Thickness } \\
\quad(\mu \mathrm{m})\end{array}$ & $\begin{array}{c}\text { N. of } \\
\text { arms } \\
\text { bundle }^{-1}\end{array}$ & $\begin{array}{c}\text { N. of } \\
\text { vessels } \\
\text { bundle }^{-1}\end{array}$ & $\begin{array}{l}\text { Thickness } \\
\quad(\mu \mathrm{m})\end{array}$ & $\begin{array}{l}\text { Thickness } \\
\quad(\mu \mathrm{m})\end{array}$ & $\begin{array}{c}\text { N. of } \\
\text { arms } \\
\text { bundle }\end{array}$ & $\begin{array}{c}\text { N. of } \\
\text { vessels } \\
\text { bundle }\end{array}$ & $\begin{array}{c}\text { Thickness } \\
(\mu \mathrm{m})\end{array}$ \\
\hline \multirow{4}{*}{ ChM } & \multirow{2}{*}{20} & $\mathbf{W}_{1}$ & $510.0 \mathrm{a}$ & $210.0 \mathrm{~b}$ & $239.3 \mathrm{a}$ & $41.7 \mathrm{~d}$ & $241.0 \mathrm{c}$ & $12.3 \mathrm{~b}$ & $50.3 \mathrm{a}$ & $272.0 \mathrm{a}$ & $205.0 \mathrm{a}$ & $4.3 \mathrm{bc}$ & $25.3 \mathrm{a}$ & $139.3 \mathrm{c}$ \\
\hline & & W 0.5 & $466.7 \mathrm{~b}$ & $133.3 \mathrm{~d}$ & $239.3 \mathrm{a}$ & 31.7 ef & $210.0 \mathrm{~d}$ & $8.3 \mathrm{~d}$ & $21.0 \mathrm{f}$ & $139.3 \mathrm{e}$ & $139.0 \mathrm{c}$ & $5.3 \mathrm{ab}$ & $13.3 \mathrm{~cd}$ & 96.7 e \\
\hline & \multirow{2}{*}{40} & $\mathbf{W}_{1}$ & $372.0 \mathrm{~d}$ & $131.7 \mathrm{~d}$ & $170.3 \mathrm{c}$ & $75.0 \mathrm{a}$ & $307.7 \mathrm{a}$ & $14.3 \mathrm{a}$ & $50.0 \mathrm{a}$ & $170.3 \mathrm{~d}$ & $139.3 \mathrm{c}$ & $4.3 \mathrm{bc}$ & $15.0 \mathrm{c}$ & $110.0 \mathrm{~d}$ \\
\hline & & W 0.5 & $416.7 \mathrm{c}$ & $172.0 \mathrm{c}$ & $139.3 \mathrm{~d}$ & $36.7 \mathrm{de}$ & $310.0 \mathrm{a}$ & $10.7 \mathrm{c}$ & $35.0 \mathrm{bc}$ & $171.7 \mathrm{~d}$ & $170.3 \mathrm{~b}$ & $5.0 \mathrm{~b}$ & $12.7 \mathrm{~cd}$ & $102.7 \mathrm{de}$ \\
\hline \multirow{4}{*}{ POC } & \multirow{2}{*}{20} & $\mathbf{W}_{1}$ & $520.0 \mathrm{a}$ & $240.0 \mathrm{a}$ & $210.0 \mathrm{~b}$ & $63.3 \mathrm{~b}$ & $210.0 \mathrm{~d}$ & $10.3 \mathrm{c}$ & $37.7 \mathrm{~b}$ & 209.7 c & $139.3 \mathrm{c}$ & $6.3 \mathrm{a}$ & $23.0 \mathrm{~b}$ & $172.0 \mathrm{~b}$ \\
\hline & & W 0.5 & $372.0 \mathrm{~d}$ & $210.0 \mathrm{~b}$ & $139.3 \mathrm{~d}$ & $26.7 \mathrm{f}$ & $236.7 \mathrm{c}$ & $9.7 \mathrm{c}$ & $30.0 \mathrm{de}$ & $270.3 \mathrm{a}$ & $110.0 \mathrm{~d}$ & $3.3 \mathrm{c}$ & $11.0 \mathrm{de}$ & $172.0 \mathrm{~b}$ \\
\hline & \multirow{2}{*}{40} & $\mathbf{W}_{1}$ & $272.0 \mathrm{f}$ & $172.0 \mathrm{c}$ & $110.0 \mathrm{e}$ & 31.7 ef & $234.3 \mathrm{c}$ & $14.3 \mathrm{a}$ & $47.3 \mathrm{a}$ & $211.7 \mathrm{c}$ & $139.0 \mathrm{c}$ & $6.3 \mathrm{a}$ & $14.0 \mathrm{c}$ & $172.0 \mathrm{~b}$ \\
\hline & & W 0.5 & $372.0 \mathrm{~d}$ & $172.0 \mathrm{c}$ & $139.3 \mathrm{~d}$ & $55.0 \mathrm{c}$ & $233.3 \mathrm{c}$ & $10.0 \mathrm{c}$ & $35.3 \mathrm{bc}$ & $210.0 \mathrm{c}$ & $139.3 \mathrm{c}$ & $4.3 \mathrm{bc}$ & $11.0 \mathrm{de}$ & $72.0 \mathrm{f}$ \\
\hline \multirow{4}{*}{ CwM } & \multirow{2}{*}{30} & $\mathbf{W}_{1}$ & $416.7 \mathrm{c}$ & $206.7 \mathrm{~b}$ & $135.0 \mathrm{~d}$ & $50.0 \mathrm{c}$ & $310.0 \mathrm{a}$ & $11.0 \mathrm{c}$ & $32.7 \mathrm{~cd}$ & $210.0 \mathrm{c}$ & $170.3 \mathrm{~b}$ & $3.3 \mathrm{c}$ & $9.0 \mathrm{e}$ & $139.3 \mathrm{c}$ \\
\hline & & W 0.5 & $472.0 \mathrm{~b}$ & $231.0 \mathrm{a}$ & $172.0 \mathrm{c}$ & $51.7 \mathrm{c}$ & $239.3 \mathrm{c}$ & $8.3 \mathrm{~d}$ & $25.7 \mathrm{e}$ & $237.0 \mathrm{~b}$ & $170.3 \mathrm{~b}$ & $4.3 \mathrm{bc}$ & $15.0 \mathrm{c}$ & $139.3 \mathrm{c}$ \\
\hline & \multirow{2}{*}{60} & $\mathbf{W}_{1}$ & $310.0 \mathrm{e}$ & $170.3 \mathrm{c}$ & $110.0 \mathrm{e}$ & $65.0 \mathrm{~b}$ & $268.7 \mathrm{~b}$ & $13.3 \mathrm{ab}$ & $51.7 \mathrm{a}$ & $172.0 \mathrm{~d}$ & $210.0 \mathrm{a}$ & $5.3 \mathrm{ab}$ & $15.0 \mathrm{c}$ & $210.0 \mathrm{a}$ \\
\hline & & W 0.5 & $410.0 \mathrm{c}$ & $172.0 \mathrm{c}$ & $172.0 \mathrm{c}$ & $51.7 \mathrm{c}$ & $238.3 \mathrm{c}$ & $10.3 \mathrm{c}$ & $34.7 \mathrm{bc}$ & $210.0 \mathrm{c}$ & $139.3 \mathrm{c}$ & $4.7 \mathrm{~b}$ & $11.0 \mathrm{de}$ & $139.3 \mathrm{c}$ \\
\hline \multicolumn{3}{|c|}{ LSD at $5 \%$} & 18.59 & 13.38 & 12.2 & 6.28 & 12.86 & 1.22 & 4.37 & 13.2 & 11.3 & 0.93 & 2.2 & 12.2 \\
\hline
\end{tabular}

Mean values followed by the same letter in each bar show non-significantly different at the $\mathrm{P}<0.05$ probability level

IWR: Irrigation water requirements W0: Well watered (2100 m-3 fad.)W 0.5: Water stressed (1050 m-3 fad.) ChM: Chicken manure POC: Pressed Olive Cake CwM: Cow manure 
ChM
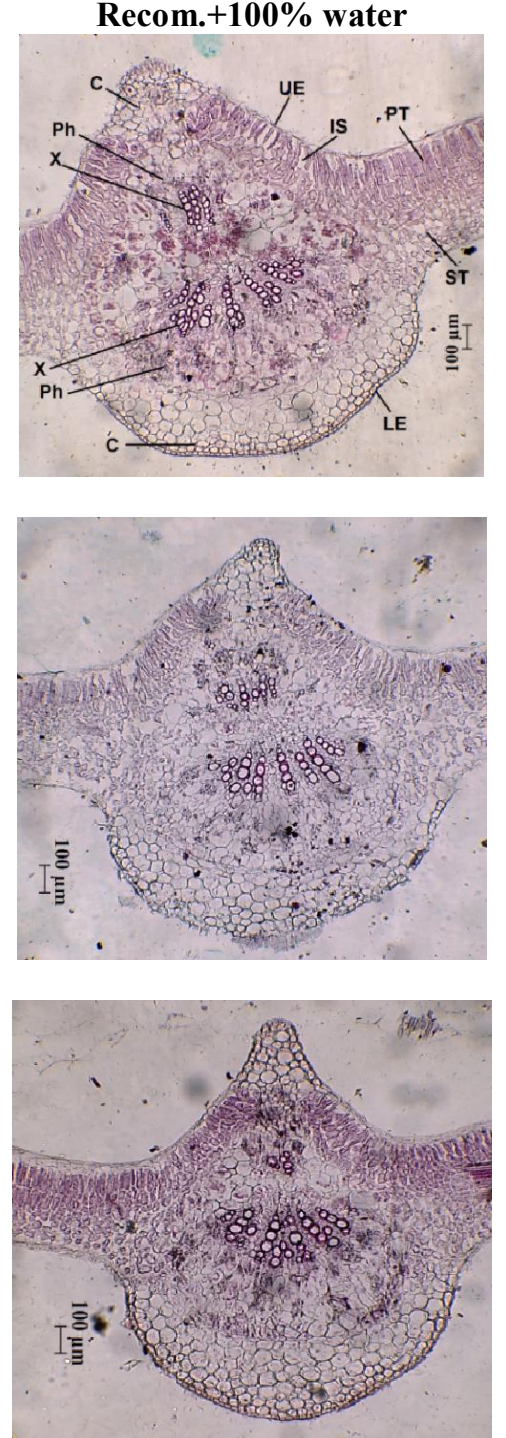
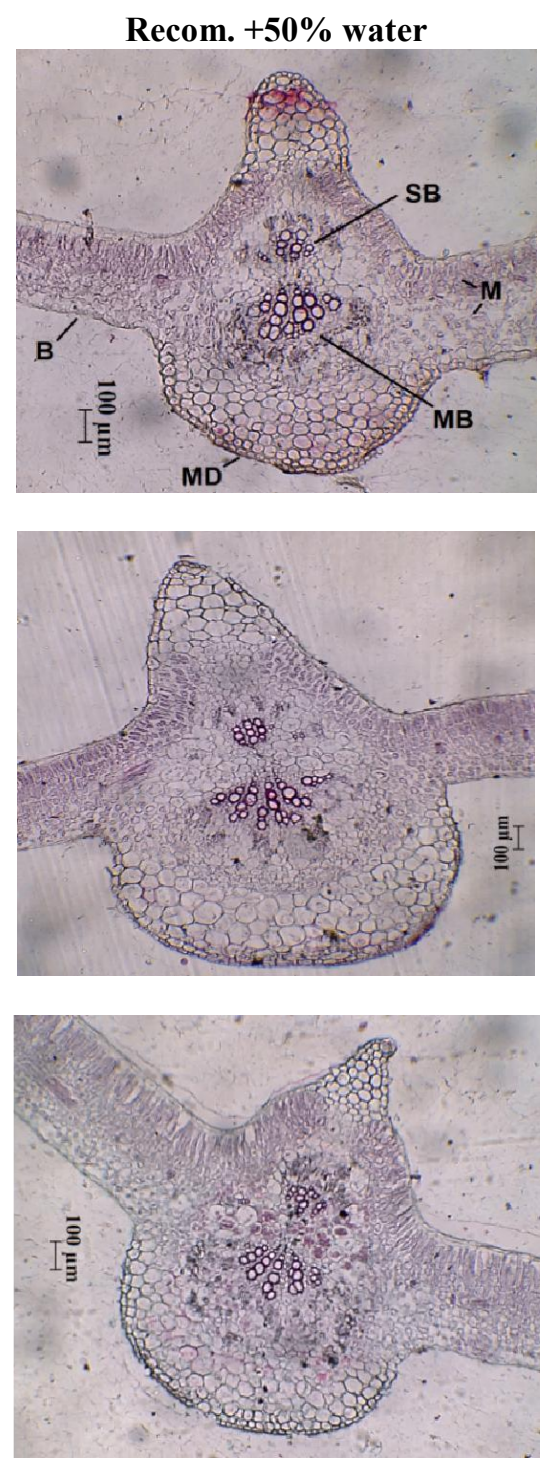

Double $+100 \%$ water
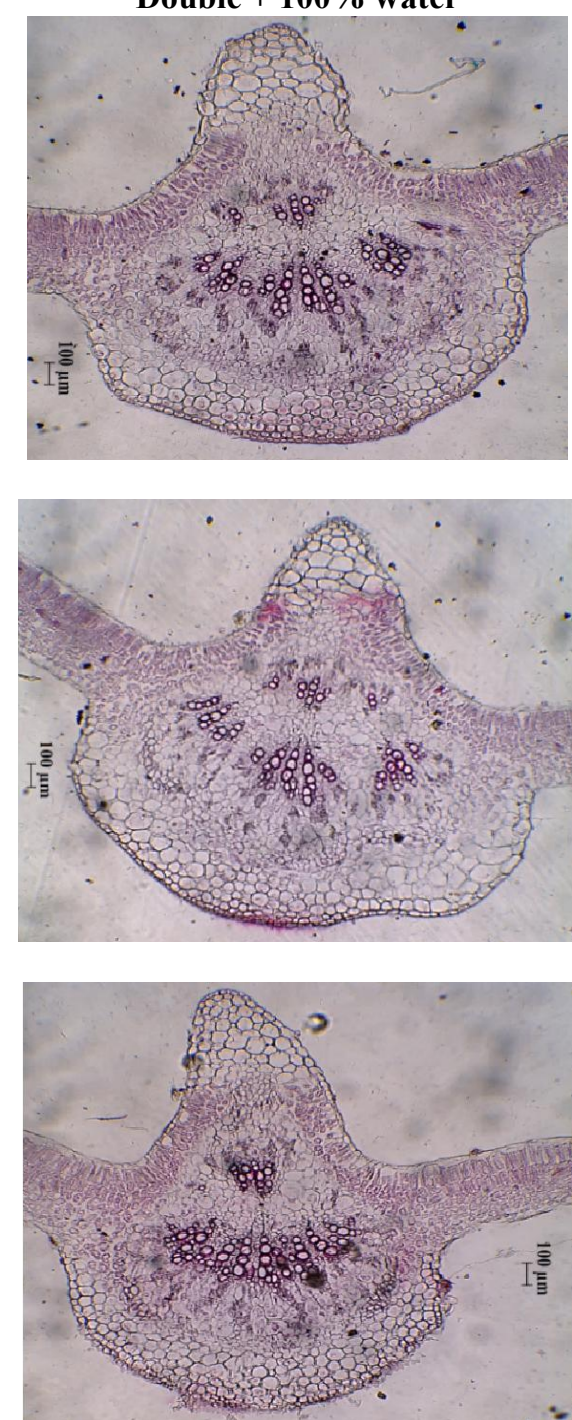

Double $+\mathbf{5 0} \%$ water
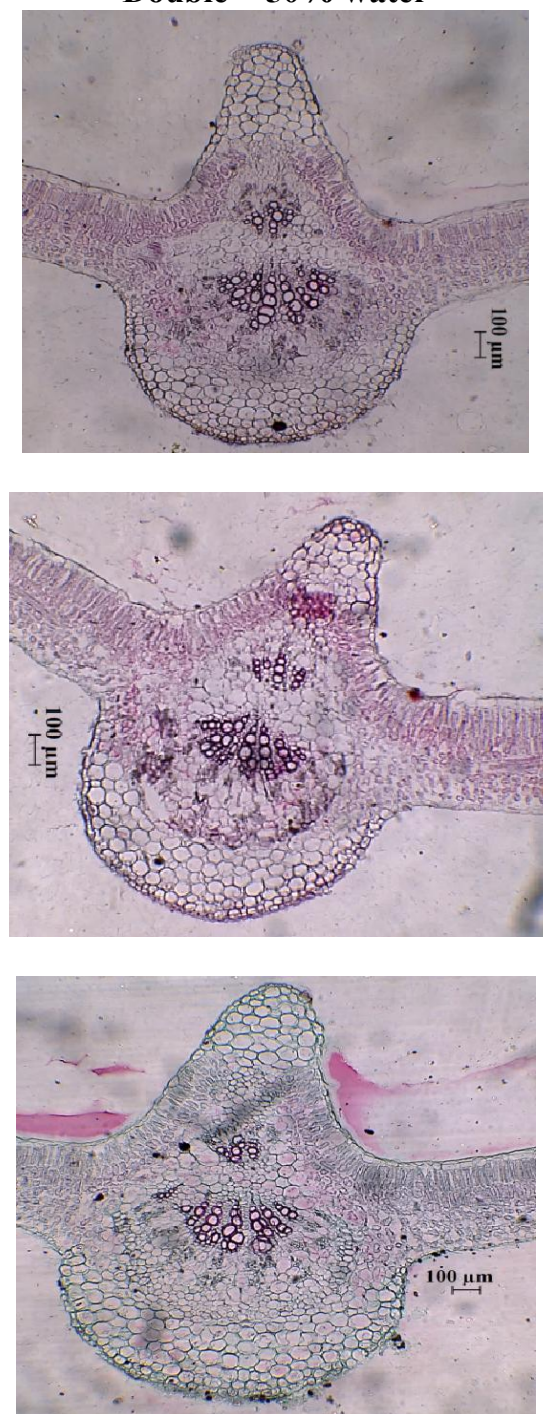

Fig. (1): Effect of organic fertilizers on anatomical characters of terminal leaflet of 3rd leaf of cowpea cultivated under different water regimes.

B, Blade; C, Collenchyma; IS, Intercellular space; LE, Lower epidermis; ; M, Mesophyll; MB, Main bundle; MD, Midrib ; Ph, Phloem; PT, Palisade tissue; SB, Second bundle ST, Spongy tissue, UE, Upper epidermis; X, xylem. 


\section{DISCUSSION}

In present study, cowpeas cultivated in alkaline sandy soil as shown in Table (2) and irrigated with saline irrigation water as shown in Table (4), whereas EC of irrigated water was 4102.4 and $4025.6 \mathrm{ppm}$, in the first and second season, respectively. Application of organic fertilizers improved the physical and chemical properties of sandy soil and preserve water among soil particles especially when added in doubled amount (Sun et al., 2003). Application of recommended and doubled amount of three different organic fertilizers was investigated under 50 and $100 \%$ of IWR. Results showed that application of recommended amount (20 $\mathrm{m}^{3}$ fed. $^{-1}$ ) of ChM to well watered-cowpeas was more efficient on stem length and leaf area due to its higher content of total nitrogen (3.1\%) as shown in Table (5) and its high decomposition compared to other organic fertilizers (Azeez and Van Averbeke, 2012). Also the $3^{\text {rd }}$ leaf of cowpea fertilized with $20 \mathrm{~m}^{3}$ fed. ${ }^{-1}$ of $\mathrm{ChM}$ had high content of $\mathrm{N}$ and $\mathrm{Na}$ (Table 10) compared to other fertilizers. This remark coordinate with that fact, nitrogen participate in amino acids synthesis as tryptophan, which represent the precursor of auxins in plants that promote the vegetative organs of cowpeas (Taiz and Zeiger, 2002). The same treatment gave the highest thickness of spongy tissue, intercellular space, and vascular elements (xylem and phloem) in the main and second vascular bundles in the leaflet of the $3^{\text {rd }}$ leaf (Table 11 and Fig. 1) which led to increase the content of reducing sugars, free phenolics, soluble protein and phosphorous as shown in Table (8), especially, under the double dose of ChM. These findings are agreed with the fact, presence of loosely mesophyll cells (palisade and spongy tissues) in leaf leads to a high assimilation efficiency of $\mathrm{CO}_{2}$ and subsequently increased the photosynthetic rate (Esau, 2006). The low dose of all three organic fertilizers under study increased the thickness and numbers of vascular elements in both the main and secondary bundles in leaflet of $3^{\text {rd }}$ leaf, led to high efficiency of organic and non-organic compounds transportation. Therefore, it improved all growth parameters (Table 6) especially, in $\mathrm{ChM}$ at the rate of $60 \mathrm{~m}^{3}$ fed. $^{-1}$ for $\mathrm{FW}$ and DW and POC at the rate of 40 $\mathrm{m}^{3}$ fed. $^{-1}$ for stem length and number of branches plant ${ }^{-1}$.

Enhancement of previous growth parameters led to the highest seed yield ( $\left.\mathrm{kg} \mathrm{fed} .^{-1}\right)$ under both recommended and doubled amount of ChM and POC fertilizers under $100 \%$ of IWR. CwM-fertilized and well irrigated cowpea gave lower amount of seed yield than ChM and POC. These findings coordinated with Ahmed and Elzaawely (2010) who found that chicken manure $\left(45 \mathrm{~m}^{3}\right.$ fed. $\left.^{-1}\right)$ combined with cattle manure $\left(21 \mathrm{~m}^{3} \mathrm{fed}^{-1}\right)$ significantly increased plant height, number of leaves, number of branches, leaf area, number of pods, seed index, seeds total yield and contents of $\mathrm{P}$ and $\mathrm{K}$ in seeds and $\mathrm{P}$ in leaves of cowpea cv. Kahalunder normal irrigation conditions. The low amount of CwM increased the content of proline and phosphorous in $3^{\text {rd }}$ leaf due to its high EC, about $2-3.5 \mathrm{ds} \mathrm{m}^{-1}$ (Azeez and Van Averbeke, 2012), therefore, decreased the growth parameters compared to other fertilizers.
Under water stress, the most estimated histological characters of leaflets of $3^{\text {rd }}$ leaf were decreased. These findings were agreed with that, water stress increases root length and thickness than shoot components. Also drought increased the thickness of cell walls and amount of cutinization and lignifications. Srivalli et al. (2003) showed that, plant must equilibrate the shoot root ratio to survive under drought conditions. In addition, leaf area index was decreased in mungbean under water stress conditions (Naresh et al., 2013).

Values of WUE increased as water deficit and with application of organic fertilizers especially POC this may be due to water movement into seeds without effect on the translocation of dry matter into the seed and this effect resulted in an increase in mass production per unit of water (Shouse et al., 1981). Although drought-tolerant species maintain water-use efficiency by reducing the water loss, longevity of drought period reduced it (Anjum et al., 2009). Cowpea showed some characters of leaf anatomy similar to drought tolerant species to increase water use efficiency as presence of several layers of palisade tissue at the expense of spongy tissue to increase the path of water through intercellular spaces to reach stomata i.e. ratio of carbon dioxide fixed to water lost. Malty-serrate palisade tissue in leaf optimizes the light interception in the early morning and in late afternoon (Lewis 1972). Also, photosynthetic capacity increased with increment of mesophyll thickness due to increase the number of chloroplasts (Oguchi et al., 2005).

Under water deficit, CwM and POC fertilizedcowpeas showed the lowest reduction of growth parameters and the higher dose compensate this reduction, contributed with increase of reducing sugars, free phenolics, soluble protein, proline and $\mathrm{Na}$ as shown in Table (10). Increment of cowpea growth and productivity after application of organic fertilizers under normal water irrigation may be due to its effect on soil microorganisms which increased the ability of mobilizing the unavailable forms of nutrient element to available forms (El-Boraie et al., 2009). Similar results were reported by Raper and Kramer (1987) who found that low productivity of cowpea under water stress associated with decreasing of photosynthetic rates and decrease the amount of photosynthates allocated to floral organs, causing increased abortion or resulting in smaller seed size. Increment of reducing sugars, proline and $\mathrm{Na}$ is one of the main mechanisms for drought tolerance to maintenance cell turgidity through osmotic adjustment (Agbicodo et al., 2009). Rhodes and Samaras, 1994 reported that under drought cytosol of plant cells accumulate different types of organic as sugars and prolineas well as inorganic solutes as potassium ions to lower osmotic potential thereby maintaining cell turgor.

The low amount of POC resulted in high thickness of mesophyll and palisade tissues in $3^{\text {rd }}$ leaf (Table 11 and Fig. 1) which may enhance the photosynthetic rate and as a result increased the content of reducing sugars, free phenolics, soluble protein and potassium (Table 10). In addition, higher dose of POC 
gave the highest $\mathrm{Chl} a, b$ and $\mathrm{a}+\mathrm{b}$ (Table 9). Therefore, number of branches and leaves plant ${ }^{-1}, \mathrm{FW}, \mathrm{DW}$ and percent of water content where in their highest values compared to $\mathrm{ChM}$ and $\mathrm{CwM}$ in well irrigated-cowpeas. Both Chl. $\mathrm{a}$ and $\mathrm{b}$ is the major photosynthetic pigments for photosynthesis and their content has a positive relationship with photosynthetic rate and declined under water stress due to oxidative stress (Farooq et al., 2009).

\section{CONCLUSION}

Application of $20 \mathrm{~m}^{3} \mathrm{fed}^{-1}$ of either ChM or POC was benefit for enhancing the growth parameters and yield components in well irrigated-cowpeas compared to CwM. Application of organic fertilizers is a beneficial practice to increase the potential of cowpea to survive under water deficit with relative reduction of yield. Addition of $40 \mathrm{~m}^{3}$ of POC or $60 \mathrm{~m}^{3}$ of $\mathrm{CwM}$ in similar condition to El-Arish area, overcome the reduction of plant growth and productivity due to drought. POC resulted in the maximum water use efficiency value. Application of POC as a cheaper and available source in El-Arish was useful than other fertilizers. Lowering the deleterious effect of drought by application of organic fertilizers was associated with enhancement of biochemical compound and tissues of leaflets.

\section{REFERENCES}

Abdel-Rahman, T., H. Thomas, G. J. Doss and L. Howell (1975). Changes in endogenous plant hormones in cherry tomato fruits during development and maturation. Physiol. Plant., 34(1): 39-43.

Addo-Quaye, A. A., A. A. Darkwa and M. K. P. Ampian (2011). Performance of three cowpea (Vigna unguiculata (L.) Walp. varieties in two agro-ecological zones of the Central Region of Ghana II: Grain yields and its components. ARPN J. Agric. and Biol. Sci., 6(2): 1-9.

Agbicodo, E. M., C. A. Fatokun, S. Muranaka and C. G. Linden van der (2009). Breeding drought tolerant cowpea: constraints, accomplishments, and future prospects. Euphytica, 167: 353-370.

Ahmed, M. E. and A. A. Elzaawely (2010). Growth and yield of cowpea plants in response to organic fertilization. Australian J. Basic and Applied Sci., 4(8): 3244-3249.

Anjum, S. A., X. Xie, L. Wang, M. F. Saleem, C. Man and W. Lei (2009). Morphological, physiological and biochemical responses of plants to drought stress. African Journal of Agricultural Research, 6(9): 2026-2032.

Arnon, D. I. (1949). Copper enzymes in isolated chloroplasts: phenol oxidase in Betavulgaris. Plant Physiol., 24: 1-15.

Azeez, J. O. and W. Van Averbeke (2012). Dynamics of soil $\mathrm{pH}$ and electrical conductivity with the application of three animal manures. Communications in Soil Sci. and Plant Analysis, 43: 865-874.
Barber, S. A. (1995). Soil nutrient bioavailability: A Mechanistic approach. New York: John Wiley and Sons Inc.

Bates, L. S., R. P. Waldren and I. D. Teare (1973). Rapid determination of free proline for water stress studies, plant soil, 39: 205-207.

Bradford, M. A. (1976). Rapid and sensitive method for the quantitation of protein utilizing the principle of protein-dye binding. Annu. Rev. Biochem., 72: 248-254.

Brown, J. D. and O. Lilleland (1946). Rapid determination of potassium and sodium in plant materials and soil extract by flame photometry. Proceedings of the Amer. Soc. Hort. Sci., 48: 341-346.

El-Bassiouny, H. M. S. and W. M. Shukry (2001). Cowpea growth pattern, metabolism and yield in response to IAA and biofertilizers under drought conditions. Egyptian J. Biol., 3: 117129.

El-Boraie, F., H. Abo-Ela and A. Gaber (2009). Water requirements of peanut grown in sandy soil under drip irrigation and bio fertilization. Australian J. Basic and Applied Sci. 3: 55-65.

Esau, K. (2006). Plant Anatomy, Meristems, Cells, and Tissues of the Plant Body: Their Structure, Function, and Development. $3^{\text {rd }}$ ed. John Wiley and Sons, Inc., pp. 601.

Fageria, N. K., V. C. Baligar and R. B. Clark (2006). Physiology of Crop Production. New York: The Haworth Press, pp: 34-318.

FAO-STAT (2012). Agricultural Data. http:// faostat.fao.org/ (last accessed, 1 June 2014).

Farouk, S. and Amany, A.R. 2012.Improving growth and yield of cowpea by foliar application of chitosan under water stress. Egyptian J. Biol., 14: $14-26$.

Ismail, S. M. (2010). Influence of deficit irrigation on water use efficiency and bird pepper production (Capsicum annuum L.), JKAU: Met., Enviro. and Arid Land Agric. Sci., 21 (2): 29-43.

Israelson, O. W. and V. C. Hansen (1962). Irrigation principles and practices $3^{\text {rd }}$ ed. John Wiley \& Sons Inc. New York, pp. 240-253.

Iuchi, S., M. Kobayashi, K. Yamaguchi-Shinozaki and K. Shinozaki (2000). A stress-inducible gene for 9-cis-epoxycarotenoid dioxygenase involved in abscisic acid biosynthesis under water stress in drought-tolerant cowpea. Plant Physiol., 123: 553-562.

Jackson, M. L. (1967). Soil Chemical Analysis. Prentice Hall, Inc., Engle wood cliff, N.J.

Lewis, M. C. (1972). The physiological significance of variation in leaf structure. Sci. Progr. Oxford, 60: $25-51$

Moore, T. C. (1974). Research experiences in plant physiology. A laboratory manual. Springerverlage. Berlin, Heidelberg, 3-12.

Naresh, R. K., Purushottam, S. P. Singh, A. Dwivedi and V. Kumar (2013). Effects of water stress on physiological processes and yield 
attributes of different Mungbean (L.) varieties Afr. J. Biochem. Res. 7(5): 55-62.

Ogbonnaya, C. I., B. Sarr, C. Brou, O. Diouf, N. N. Diop and H. Roy-Macauley (2003). Selection of cowpea genotypes in hydroponics, pots, and field for drought tolerance, Crop Sci., 43: 1114-1120.

Oguchi, R., K. Hikosaka and T. Hirose (2005). Leaf anatomy as a constraint for photosynthetic acclimation: differential responses in leaf anatomy to increasing growth irradiance among three deciduous trees. Plant Cell Environ, 28: 916-927

Pandey, R. K., W. A. T. Herrera and J. W. Pendleton (1984). Drought response of grain legumes under irrigation gradient. I. Yield and yield components. Agron. J., 76 (4): 549-553.

Piper, C. S. (1950). Soil and Plant Analysis. Inter science publishers, Inc., New York.

Raper, C. D. and P. J. Kramer (1987). Stress Physiology, p. 589-641. In J.R. Wilcox (ed.) Soybeans: Improvement, Production and Uses, $2^{\text {nd }}$ ed. ASA, Madison, WI.

Rhodes, D. and Y. Samaras (1994). Genetic control of osmoregulation in plants. In cellular and molecular physiology of cell volume regulation. Strange, K. Boca Raton: CRC Press, pp. 347-361.

Richards, L. A. (1954). Diagnosis and Improvement of Saline and Alkaline Soils. U.S.D.A. Handbook, No.60.

Rochfort, S. and J. Panozzo (2007). Phytochemicals for Health, the Role of Pulses. J. Agric. and Food Chemist., 55: 7981-7994.
Rosen, H. (1957). A modified ninhydrincolourimetric analysis for amino acids. Arch. Biochem. Biophys, 67: 10-15.

Shangguan, Z., M. Shao and J. Dyckmans (2000). Effects of nitrogen nutrition and water deficit on net photosynthetic rate and chlorophyll fluorescence in winter wheat. J. Plant Physiol., 156: 46-51.

Shouse, P., S. Desberg, W. A. Jury and L. H. Stolzy (1981). Water deficit effects on water potential, yield and water use of cowpeas. Agro. J., 73: 333 - 336.

Srivalli, B., V. Chinnusamy and R. K. Chopra (2003). Antioxidant defense in response to abiotic stresses in plants. J. Plant Biol., 30: 121-139.

Sun, R., B. Zhao and L. Zhu (2003). Effect of long-term fertilization on soil enzyme activities and its role in adjusting-controlling soil fertility. Plant Nutrition and Fertilizer Sci., 9:406-410.

Taiz, L. and E. Zeiger (2002). Plant Physiology. Sinauer Associates, $3^{\text {rd }}$ ed., p.690.

Willey, R. L. (1971). Micro technique. In: A Laboratory Guide, McMillan Publishing Inc., NY, pp. 99.

William, H. P., A. C. Chichilo and H. Reynolds (1965). Official Methods of Analysis of the Association of Agricultural Chemists. $10^{\text {th }}$ Ed., Ass. Agric. chem., Washington, D.C, 158.

Yaron, B., E. Danfors and Y. Vaddia (1973). Arid zone irrigation. Springer-Verlag Berlin, Heidelberg, New York.

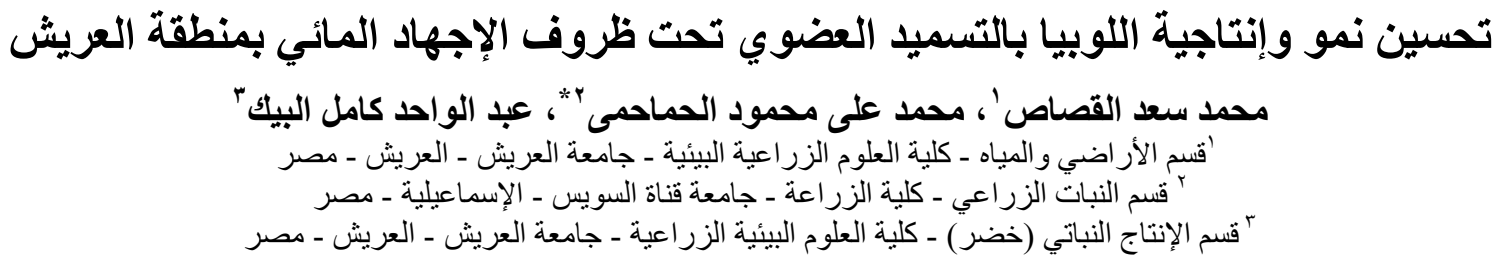

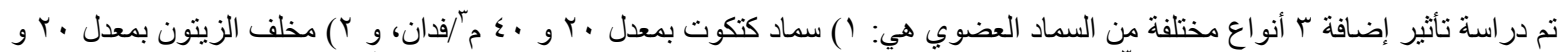

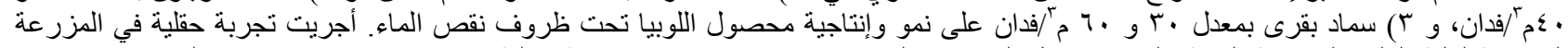

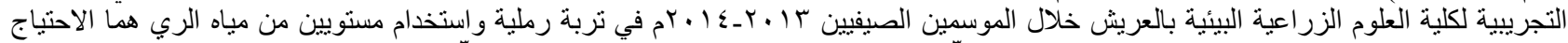

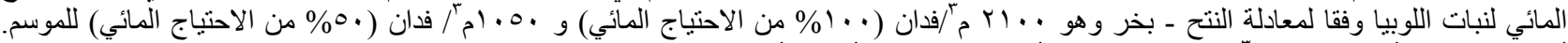

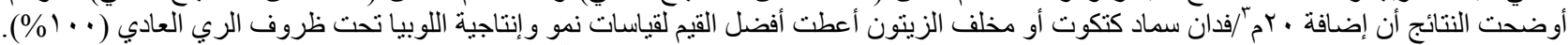

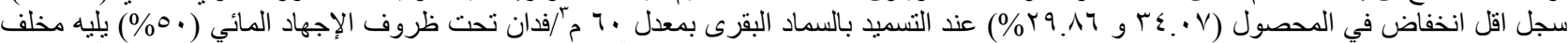

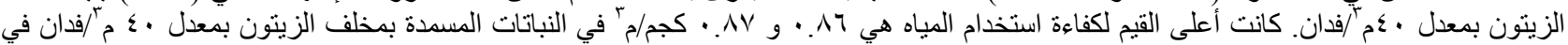

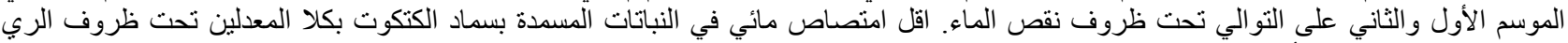

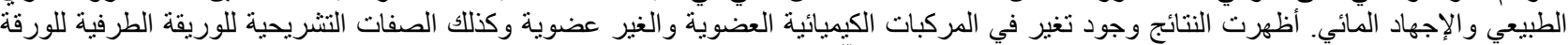

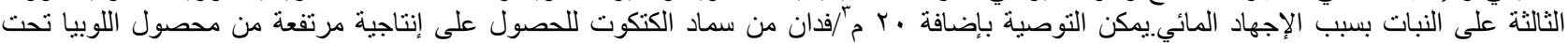

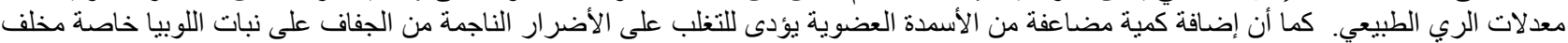

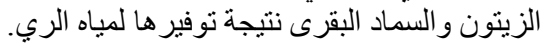

